\title{
End-of-life vehicle management: a comprehensive review
}

\author{
Selman Karagoz ${ }^{1}$ (D) Nezir Aydin ${ }^{2} \cdot$ Vladimir Simic $^{3}$
}

Received: 7 August 2019 / Accepted: 7 November 2019 / Published online: 16 November 2019

(c) The Author(s) 2019

\begin{abstract}
Waste management is gaining very high importance in recent years. As automotive is one of the most critical sectors worldwide, which is rapidly increasing, the management of end-of-life vehicles (ELVs) gains importance day by day. Due to legislation and new regulations, actors like users, producers, and treatment facilities are being conferred new responsibilities in the ELV management process. Besides, the ELV management is of vital importance for environment conservation, circular economy and sustainable development. All of these reasons are making the ELV management such a crucial issue to study. Today, the ELV management is a well-positioned and emergent research area. However, the available review papers are focused only on a small area of the ELV management, such as reverse logistics, recovery infrastructure, disassemblability, etc. Besides, a review of state-of-the-art mathematical models for the ELV management is still missing. This paper aims to provide an extensive content analysis overview of studies on the ELV management. A total of 232 studies published in the period 2000-2019 are collected, categorized, reviewed and analyzed. A critical review of the published literature is provided. Gaps in the literature are identified to clarify and suggest future research directions. This review can provide a source of references, valuable insights, and opportunities for researchers interested in the ELV management and inspire their additional attention.
\end{abstract}

Keywords End-of-life vehicle $\cdot$ Management $\cdot$ Waste $\cdot$ Recycling $\cdot$ Review

\section{Introduction}

As a result of industrialization, environmental pollution has become one of the most crucial issues of today. According to the Organization for Economic Cooperation and Development (OECD), the total number of registered vehicles in OECD/Europe countries has grown by $4 \%$ a year within the period of 2014-2018 [1]. Figure 1 shows worldwide automobile production from 2000 to 2017 (in million vehicles) [2]. As the automotive sector generates about $5 \%$ of industrial waste in the entire world [3], recycling of end-of-life vehicles (ELVs) is not only an environmental issue to deal with but also a financial source for the industries.

Selman Karagoz

selman.karagoz@nottingham.ac.uk;

karagozselman@gmail.com

1 School of Computer Science, University of Nottingham, Jubilee Campus, NG8 1BB Nottingham, UK

2 Department of Industrial Engineering, Yildiz Technical University, 34349, Besiktas, Istanbul, Turkey

3 Faculty of Transport and Traffic Engineering, University of Belgrade, Vojvode Stepe 305, 11000 Belgrade, Serbia
ELVs are classified as hazardous waste and have the potential for polluting the environment if they are not managed properly [4]. They are the single largest hazardous waste category from households [5]. They represent a category of waste whose processing is especially difficult because of their complex structure and varied composition. As the number of ELVs is estimated to increase to approximately 80 million units per year by 2020 [6], there is strong motivation to effectively manage this fast-growing waste flow.

The ELV management includes the management of all related activities and material, financial, and information flows between and among the ELV network entities; i.e., vehicle users, collection centers, authorized dismantling facilities, shredders, recycling centers, remanufacturing facilities, second-hand markets, industrial landfills sites, etc. It is of vital importance for environment conservation, circular economy and sustainable development. This process is not only profit-oriented. The management of ELVs is significantly dependent on legislation, like Directive 2000/53/ EC [7] in the European Union, Law on recycling of ELVs [8] in Japan, Technical policy for the recovery and utilization of automobile products [9] in China, Act on the resource 


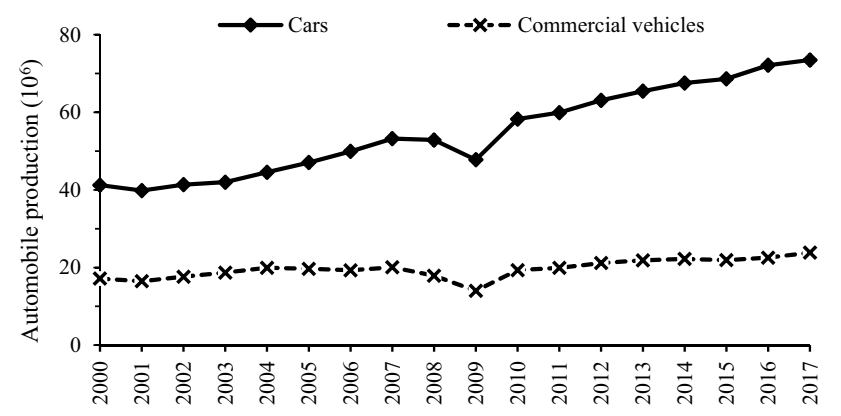

Fig. 1 Worldwide automobile production from 2000 to 2017 (Statista Portal, 2019)

circulation of electrical and electronic equipment and vehicles [10] in Korea, etc. Sound management of ELVs has become the principal sustainability issue in most countries worldwide and therefore requires sophisticated decisionmaking tools for optimizing its efficiency.

Today, the ELV management is a well-positioned and emergent research area. Recently, some review papers have been published (Table 1). They should be presented here to highlight the need for this research. Table 1 overviews 21 review studies from the literature in the field of
ELV management regarding their scope, analyzed period and number of reviewed papers. It shows that the available review papers are focused only on a small area of the ELV management, such as reverse logistics, recovery infrastructure, disassemblability, treatment processes, etc. In addition, a review of state-of-the-art mathematical models for the ELV management is still missing from the available reviews. The last line in Table 1 can present the role of this review paper in covering the identified gap of the literature. It is necessary to have a comprehensive review of the ELV management area to help researchers focus on future directions. Therefore, in this paper, we present a holistic view of the ELV management research area by covering a wide range of published work.

This paper systematically investigates the current research within the area of the ELV management by classifying 232 peer-reviewed published references. Its primary purpose is to provide an extensive content analysis overview of stateof-the-art research published in the period 2000-2019. Studies on the ELV management are classified based on their objectives, methodology, parameter types used in the case, type of supply chains, number, and type of objective functions. Moreover, studies that have used mathematical optimization are analyzed independently based on the type of

Table 1 Summary of (available) review papers in the field of ELV management

\begin{tabular}{|c|c|c|c|}
\hline Author(s) and year & Scope & Analyzed period & $\begin{array}{l}\text { Number of } \\
\text { reviewed } \\
\text { papers }\end{array}$ \\
\hline Nourreddine (2007) [12] & (Automotive) shredder residue treatment & 1991-2004 & 26 \\
\hline Vermeulen et al. (2011) [16] & & 1994-2011 & $\sim 150$ \\
\hline Zorpas and Inglezakis (2012) [18] & & 1978-2010 & $\sim 110$ \\
\hline Cossu and Lai (2015) [27] & & 2005-2014 & $\sim 120$ \\
\hline De Almeida and Borsato (2019) [31] & & 1999-2016 & 76 \\
\hline Kumar and Sutherland (2008) [13] & Vehicle recovery infrastructure & 1986-2007 & 73 \\
\hline Hiratsuka et al. (2014) [24] & & 1995-2012 & 26 \\
\hline Go et al. (2011) [17] & Disassemblability & 1992-2010 & 38 \\
\hline Mayyas et al. (2012) [19] & Sustainability of the automotive industry & 1984-2011 & $\sim 90$ \\
\hline Bari et al. (2011) [14] & Automotive waste & 2010 & 103 \\
\hline Kindzierski et al. (2013) [15] & & 2012 & 107 \\
\hline Simic (2013) [3] & Environmental engineering issues & 2003-2012 & 93 \\
\hline Lashlem et at. (2013) [20] & Management practices & 1995-2012 & 20 \\
\hline Sakai et al. (2014) [23] & & 1991-2012 & $\sim 90$ \\
\hline Li et al. (2014) [22] & & 2005-2012 & 16 \\
\hline Gan and $\mathrm{He}(2014)$ [21] & Reverse logistics & $2002-2013$ & 38 \\
\hline Cin and Kusakci (2017) [30] & & 2005-2016 & 23 \\
\hline Zhang and Chen (2014) [26] & Automotive plastics & 1993-2012 & 63 \\
\hline Buekens and Zhou (2014) [25] & Automotive shredder residue plastics & 1977-2012 & 76 \\
\hline Cucchiella et al. (2016) [28] & Automotive electronics & 2000-2014 & $\sim 50$ \\
\hline Rosa and Terzi (2016) [29] & & 2001-2015 & 35 \\
\hline Our review & Whole area & 2000-2019 & 232 \\
\hline
\end{tabular}


decision variables, optimization model types, single-multi objectivity, and solution approach. Gaps in the literature are identified to clarify and suggest future research directions.

The remaining part of the paper is organized as follows: Sect. "Review methodology" describes a review methodology. Classification is provided in Sect. "Classification". Sections "Classification" and "Results of the literature review" present the obtained results of the review and discussion, respectively. The last section presents the paper's main conclusions and recommendations.

\section{Review methodology}

In this study, Content analysis (CA) was inspired to review the literature. $\mathrm{CA}$ is a research technique based on interpreting and coding textual material to convert qualitative data into quantitative data [11].

Furthermore, only peer-reviewed publications (i.e., international journals, book chapters, etc.) were reviewed. Search engines were used to explore ACS Publications, ASCE Library, ASME Digital Library, Cambridge Journals, EBSCOhost, EmeraldInsight, Google Scholar, IEEE Xplore, Inderscience, IntegraConnect, IOPScience, J-STAGE, JSTOR, ProQuest, RSCPublishing, SAGE journals, ScienceDirect, SciVerse, SpringerLink, and WILEY databases for literature. Publications were searched with the keyword of "End of life vehicles". In addition, the references cited in each relevant literature were examined to find out additional sources of information. Finally, rigor in validity is achieved by validation tests using the deductive and inductive approaches simultaneously.

\section{Classification}

Being a complex and multidisciplinary subject, ELV management review studies are classified and analyzed based on various types of subjects. For instance, Simic [3] classified the publications related to the ELVs recycling into three major categories: "Vehicle recycling practices world-wide", "Legislation-oriented research" and "Remanufacturing and materials recycling". Therefore, major categories were classified according to their approaches; e.g., "Life Cycle Assessment", "Production planning", "Material selection", etc.

In this study, ELVs-related publications are classified into four major categories: (1) literature survey, (2) recycling, production and planning, (3) network design and (4) regulations review. Furthermore, methods of the studies are presented as a sub-category. Figure 2 presents the major classification of the study.

In addition, publications including mathematical models were analyzed additionally. Cin and Kusakci [30] clustered reverse logistics of ELVs studies based on network structure, optimization model, objective function, methods to handle uncertainty and solution approach. Different from Cin and Kusakci [30], not only logistics networks of ELVs but also other types of ELVs (e.g., production planning, recycling process planning, location-allocation, etc.) studies with an optimization model are reviewed based on the type of decision variables, optimization model and solution approach. The aim of these classifications is to categorize the studies and make them more visible and summarizer for the researchers.

\section{The major classification of the study}

The publications were classified into four major categories: (1) literature survey (LS), (2) recycling, production

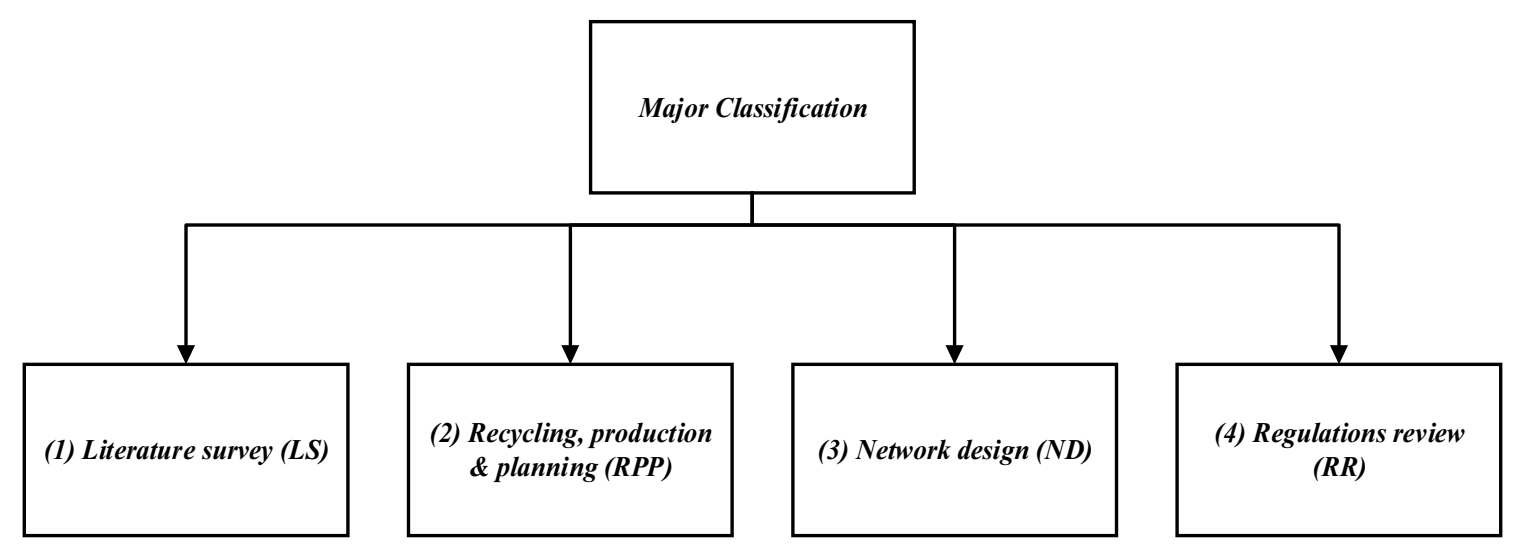

Fig. 2 The major classification of the reviewed publications 
and planning (RPP), (3) network design (ND) and (4) regulations review.

1. Literature survey $(L S)$ In this sub-category, surveys that are in the scope of this research were investigated.

2. Recycling, production and planning (RPP) In this subcategory, studies aiming to analyze and suggest solutions for tactical decisions about recycling processes, material types, product design, and production planning were categorized.

3. Network design (ND) Studies that are suggesting approaches to cope with strategical decisions about supply chain issues in the ELV management process were categorized under this sub-section.

4. Regulations review $(R R)$ As legislations play an important role in ELVs' recycling, studies related to regulation analyses were categorized in this sub-category.

\section{Methods}

The studies reviewed in this paper were classified into 23 categories and 29 sub-categories by the applied methods. Figure 3 presents the summary of used methods in the reviewed studies.

\section{Single-multi objectivity}

In this section, studies with mathematical modeling approaches were classified into two sections based on the number of their objective functions: (1) single-objective (SO) and (2) multi-objective (MO).

\section{Type of objective function}

In addition to the single-multi objectivity section, studies with a mathematical model were classified based on the type

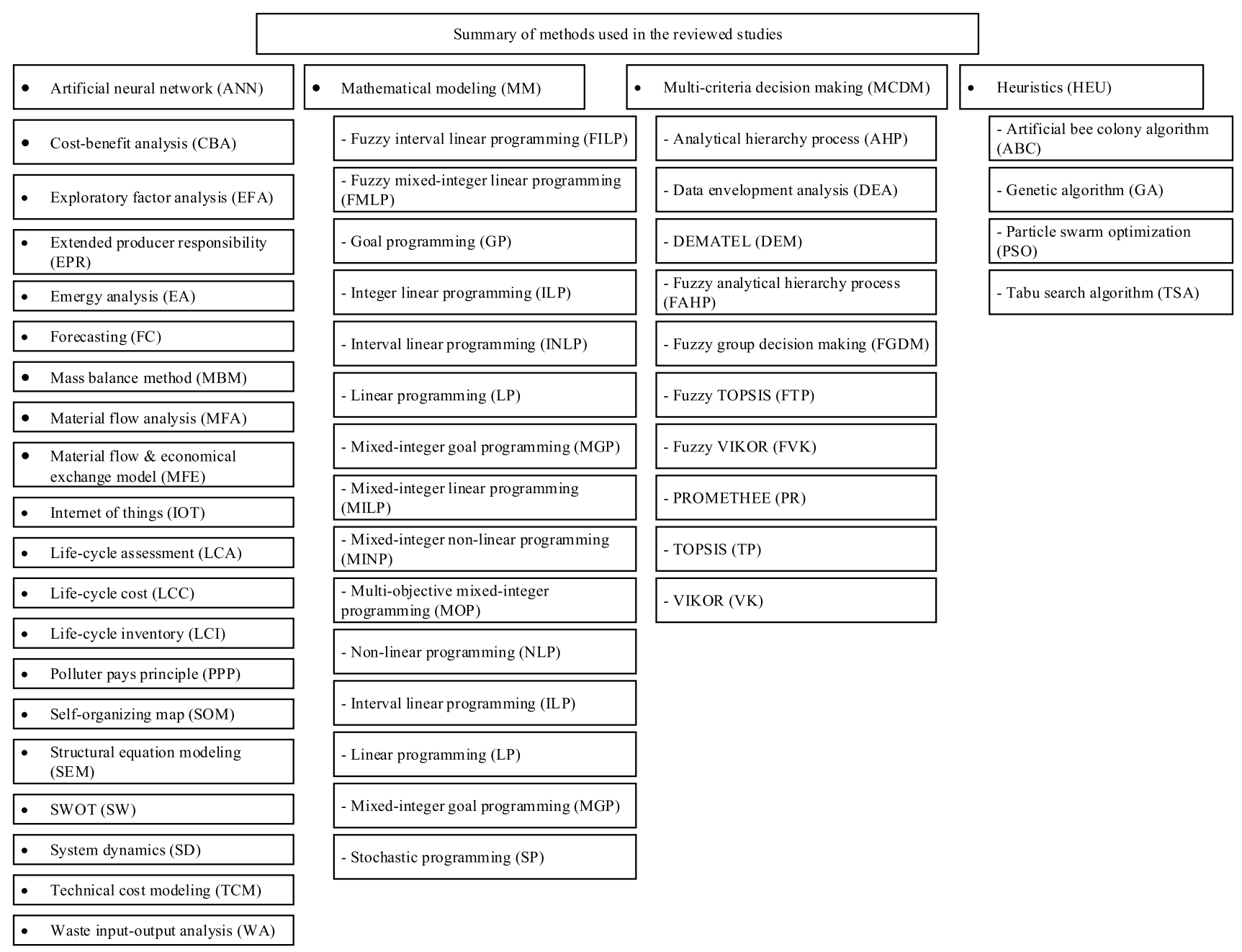

Fig. 3 Classification of methods used in the reviewed studies 
of their objective function(s): (1) maximization (Max) and (2) minimization (Min).

\section{Type of parameter}

In this section, studies were classified into three sub-categories based on parameter type used in the publication: (1) deterministic (Det.), (2) probabilistic (Prob.) and (3) fuzzy.

\section{Type of supply chain}

As transportation of ELVs and its components is one of the most indispensable activities in the ELV management, the reviewed studies were classified into two sub-categories based on supply chain type: (1) open loop (OL), and (2) closed loop (CL).

\section{Type of decision variables}

Based on the type of decision variables in the studies with a mathematical model, publications were classified into three sub-categories: (1) location allocation (LA), (2) recycling planning (RP), (3) production planning (PP).

\section{Optimization model}

In this section, studies with mathematical models were classified into four sub-categories: (1) linear programming (LP), (2) non-linear programming (NLP), (3) mixed-integer linear programming (MILP), and (4) mixed-integer non-linear programming (MINP).

\section{Solution approach}

In this section, studies were classified into three sub-categories based on their solution approaches (1) exact (E), (2) heuristics $(\mathrm{H})$ and (3) meta-heuristics $(\mathrm{MH})$.

\section{Results of the literature review}

While the ELV management was in its infancy 20 years ago, today it is a well-recognized and growing research area. The main reason for this is the introduction of Directive 2000/53/ EC. More detailed, Directive 2000/53/EC of the European Parliament and of the Council of 18 September 2000 on end-of-life vehicles was introduced in the year 2000 [7]. It fundamentally changed the business philosophy of the vehicle recycling industry. This change started the evolution of the ELV management that has taken place in the last two decades. Since the year 2000, a lot of activity has taken place in the ELV management research area, which has come into focus. Besides, many new sub-areas also have emerged. In view of that, 232 publications in the period of 2000-2019, are collected and classified based on the purpose of the study. This classification generates the main framework of the review. A summary of the overall literature review according to their classification is presented in Table 2 .

\section{Literature survey}

Table 1 overviews 21 review studies in the literature regarding their research focus, analyzed period and number of reviewed papers. They should be presented here to highlight the need for this research. Nourreddine [12] provided an overview of several automobile shredder residue (ASR) treatment processes. Kumar and Sutherland [13] presented an overview of studies on the vehicle recovery infrastructure. A review of the literature published in the years 2010 and 2012 on topics relating to automotive wastes was presented in Bari et al. [14] and Kindzierski et al. [15], respectively. Vermeulen et al. [16] critically reviewed ELV processingrelated issues. Go et al. [17] presented a review of several disassemblability methods, including a spreadsheet-like chart, end-of-life value and time for disassembly. Zorpas and Inglezakis [18] investigated the ASR problem and the options for its processing. Mayyas et al. [19] investigated the sustainability research within the vehicle industry, through a review of the different studies in vehicles' life cycle, disposal, and end-of-life treatment. Lashlem et al. [20] presented a brief review of ELV management practices worldwide. Simic [3] reviewed the environmental engineering issues of ELV recycling by covering a wide range of peer-reviewed journal papers. Gan and $\mathrm{He}$ [21] presented a short review of ELV reverse logistics. Li et al. [22] provided an overview of present ELV management practices in China. Sakai et al. [23] provided a comparative analysis of ELV management practices in several countries. Hiratsuka et al. [24] discussed the background of the establishment of the ELV recycling system in Japan, its features and perspectives. Buekens and Zhou [25] reviewed the most prominent options for recycling plastics from ASR. Zhang and Chen [26] discussed ELV-related regulations in the USA, the EU, Japan, Korea, and China, and analyzed accessible recycling technologies for automotive plastic components. Cossu and Lai [27] presented a general overview of post shredder technologies for the treatment of ASR. Cucchiella et al. [28] provided a mini-review on the automotive electronics recycling topic. Rosa and Terzi [29] compared ELV and WEEE waste streams through a structured literature analysis under several perspectives by evidencing current differences and potential commonalities. Cin and Kusakci [30] presented a brief review of reverse logistics networks for ELVs. De Almeida and Borsato [31] provided a bibliometric literature review to assess the efficiency of the available treatment of end-of-life products. 
Table 2 Summary of RPP publications on the ELV management

\begin{tabular}{|c|c|c|c|c|c|c|c|c|c|c|c|c|c|c|c|c|c|}
\hline \multirow[t]{2}{*}{ Year } & \multirow[t]{2}{*}{ Author(s) } & \multicolumn{16}{|c|}{ Method(s) used in the study } \\
\hline & & $\mathrm{FC}$ & GP & LCA & LCC & LCI & LP & MBM & MFE & MILP & MM & MOP & NLP & PPP & PR & SD & TCM \\
\hline 2000 & Kirkpatrick et al. [32] & & & $\checkmark$ & & & & & & & & & & & & & \\
\hline 2000 & Bellman and Khare [33] & & & & & & & & & & & & & $\checkmark$ & & & \\
\hline 2000 & Hartman et al. [34] & & & $\checkmark$ & & & & & & & & & & & & & \\
\hline 2000 & Hoffmann and Wilson [181] & & & $\checkmark$ & & & & & & & & & & & & & \\
\hline 2001 & Díaz and Fernández [35] & & & $\checkmark$ & & & & & & & & & & & & & \\
\hline 2001 & Mark et al. [36] & & & & $\checkmark$ & & & & & & & & & & & & \\
\hline 2001 & Johnson and Wang [37] & & & & & & & & & & & & & & & & $\checkmark$ \\
\hline 2001 & Petrov [38] & & & $\checkmark$ & & & & & & & & & & & & & \\
\hline 2002 & Johnson and Wang [39] & & & & & & & & $\checkmark$ & & & & & & & & \\
\hline 2002 & Van Schaik et al. [40] & & & & & & & & & & $\checkmark$ & & & & & $\checkmark$ & \\
\hline 2003 & Boon et al. [41] & & $\checkmark$ & & & & & & & & & & & & & & \\
\hline 2003 & Petrov [42] & & & $\checkmark$ & & & & & & & & & & & & & \\
\hline 2003 & Castro et al. [43] & & & $\checkmark$ & & & & & & & & & & & & & \\
\hline 2004 & Gesing [44] & & & $\checkmark$ & & & & & & & & & & & & & \\
\hline 2004 & Mark and Kamprath [45] & & & $\checkmark$ & & & & & & & & & & & & & \\
\hline 2004 & Van Schaik and Reuter [46] & & & & & & & & & & & & & & & $\checkmark$ & \\
\hline 2004 & Van Schaik et al. [47] & & & & & & & & & & & & $\checkmark$ & & & & \\
\hline 2004 & Kim et al. [48] & & & & & & & $\checkmark$ & & & & & & & & & \\
\hline 2004 & Schmidt et al. [49] & & & $\checkmark$ & & & & & & & & & & & & & \\
\hline 2004 & Pelletiere and Reinert [50] & $\checkmark$ & & & & & & & & & & & & & & & \\
\hline 2004 & Bandivadekar et al. [51] & & & & & & & & $\checkmark$ & & & & & & & $\checkmark$ & \\
\hline 2005 & Sawyer-Beaulieu and Tam [52] & & & $\checkmark$ & & & & & & & & & & & & & \\
\hline 2005 & Seo et al. [53] & & & $\checkmark$ & & & & & & & & & & & & & \\
\hline 2005 & Choi et al. [54] & & & & & & & & & $\checkmark$ & & & & & & & \\
\hline 2005 & Castro et al. [55] & & & & & & & & & & & & & & & $\checkmark$ & \\
\hline 2005 & Forslind [56] & & & $\checkmark$ & & & & & & & & & & & & & \\
\hline 2006 & Chen [57] & & & $\checkmark$ & & & & & & & & & & & & & \\
\hline 2006 & Ferrao et al. [58] & & & $\checkmark$ & & & & & & & & & & & & & \\
\hline 2006 & Krinke et al. [59] & & & $\checkmark$ & & & & & & & & & & & & & \\
\hline 2006 & Reuter et al. [60] & & & & & & $\checkmark$ & & & & & & & & & & \\
\hline 2006 & Forton et al. [61] & & & $\checkmark$ & & & & & & & & & & & & & \\
\hline 2006 & Finkbeiner et al. [62] & & & $\checkmark$ & & & & & & & & & & & & & \\
\hline 2006 & Mazzanti and Zoboli [63] & & & & & & & & & & & & & & & $\checkmark$ & \\
\hline 2006 & Amaral et al. [64] & & & & & & & & & & & & & & & $\checkmark$ & \\
\hline 2006 & Ferrao and Amaral [65] & & & & & & & & & & & & & & & & $\checkmark$ \\
\hline 2006 & Pelletiere and Reinert [66] & $\checkmark$ & & & & & & & & & & & & & & & \\
\hline 2007 & Coates and Rahimifard [67] & & & & & & & & & & $\checkmark$ & & & & & & $\checkmark$ \\
\hline 2007 & Jeong et al. [68] & & & $\checkmark$ & & & & & & & & & & & & & \\
\hline 2007 & Joung et al. [69] & & & $\checkmark$ & & & & & & & & & & & & & \\
\hline 2007 & Mergias et al. [70] & & & & & & & & & & & & & & $\checkmark$ & & \\
\hline 2007 & Dalmijn and De Jong [71] & & & $\checkmark$ & & & & & & & & & & & & & \\
\hline 2007 & Giannouli et al. [72] & $\checkmark$ & & & & & & & & & & & & & & & \\
\hline 2007 & Sakai et al. [73] & & & $\checkmark$ & & & & & & & & & & & & & \\
\hline 2007 & Williams et al. [74] & & & & & & & & & $\checkmark$ & & & & & & & \\
\hline 2007 & Alonso et al. [75] & & & $\checkmark$ & $\checkmark$ & & & & & & & & & & & & \\
\hline 2007 & Frad and Revnic [76] & & & $\checkmark$ & & & & & & & & & & & & & \\
\hline 2007 & Ribeiro et al. [77] & & & $\checkmark$ & & & & & & & & & & & & & \\
\hline 2007 & Fuse et al. [78] & $\checkmark$ & & & & & & & & & & & & & & & \\
\hline
\end{tabular}


Table 2 (continued)

\begin{tabular}{|c|c|c|c|c|c|c|c|c|c|c|c|c|c|c|c|c|c|c|}
\hline \multirow[t]{2}{*}{ Year } & \multirow[t]{2}{*}{ Author(s) } & \multicolumn{17}{|c|}{ Method(s) used in the study } \\
\hline & & FC & GP & LCA & LC & $\mathrm{CC}$ & II LP & & BM & MFE & MILP I & MM I & MOP I & NLP & PPP & PR & SD & TCM \\
\hline 2008 & Ignatenko et al. [79] & & & & & & & & & & & & $\checkmark$ & & & & & \\
\hline 2008 & Qi and Hongcheng [80] & & & & & & & & & & $\checkmark$ & & & & & & & \\
\hline 2008 & Sawyer-Beaulieu and Tam [81] & & & & & $\checkmark$ & & & & & & & & & & & & \\
\hline \multirow[b]{2}{*}{ Year } & \multirow[b]{2}{*}{ Author(s) } & \multicolumn{17}{|c|}{ Method(s) used in the study } \\
\hline & & EPR & $\mathrm{FC}$ & GA & ILP & LCA & LCI & LP & MFA & MFE & E MILP & MM & MOP & NLP & SD & SW & TCM & WA \\
\hline 2008 & Smith and Keoleian [82] & & & & & & $\checkmark$ & & & & & & & & & & & \\
\hline 2008 & Fuse and Kashima [83] & & $\checkmark$ & & & & & & & & & & & & & & & \\
\hline 2008 & Qu and Williams [84] & & & & & & & & & & & & $\checkmark$ & & & & & \\
\hline 2009 & Chondros [85] & & & & & & & & & & $\checkmark$ & & & & & & & \\
\hline 2009 & Puri et al. [86] & & & & & & $\checkmark$ & & & & & & & & & & & \\
\hline 2009 & Amelia et al. [87] & & & & & $\checkmark$ & $\checkmark$ & & & & & & & & & & & \\
\hline 2009 & Chen and Zhang [88] & & & & & & & & & & & & & & & & & $\checkmark$ \\
\hline 2009 & Kumar and Sutherland [89] & & & & & & & & & & & & & $\checkmark$ & & & & \\
\hline 2009 & Fuse et al. $[90,91]$ & & & & & $\checkmark$ & & & & & & & & & & & & \\
\hline 2009 & Zoraga et al. [102] & & & & & $\checkmark$ & & & & & & & & & & & & \\
\hline 2009 & Haefliger et al. [182] & & & & & $\checkmark$ & & & & & & & & & & & & \\
\hline 2010 & Santini et al. [92] & & & & & & & & & & & & & & & $\checkmark$ & & \\
\hline 2010 & Chen et al. [93] & & & & & $\checkmark$ & & & & & & & & & & & & \\
\hline 2010 & Go et al. [94] & & & & & & & & & $\checkmark$ & & & & & & & & \\
\hline 2010 & Mathieux and Brissaud [95] & & $\checkmark$ & & & & & & & & & & & & & & & \\
\hline 2011 & Agbo [96] & & $\checkmark$ & & & & & & & & & & & & & & & \\
\hline 2011 & $\begin{array}{l}\text { Duranceau and Sawyer-Beau- } \\
\text { lieu [97] }\end{array}$ & & & & & & & & & & & & & & $\checkmark$ & & $\checkmark$ & \\
\hline 2011 & Hedayati and Subic [98] & & & & & $\checkmark$ & & & & & & & & & & & & \\
\hline 2011 & Kibira and Jain [99] & & & $\checkmark$ & & & & & & & & $\checkmark$ & & & & & & \\
\hline 2011 & Santini et al. [100] & & & & & & & & $\checkmark$ & & & & & & & & & \\
\hline 2011 & Xi et al. [101] & & & & & $\checkmark$ & & & & & & & & & & & & \\
\hline 2011 & Che et al. [103] & & & & & $\checkmark$ & & & & & & & & & & & $\checkmark$ & \\
\hline 2011 & Nazmi et al. [104] & & & & & & & & & & & $\checkmark$ & & & & & & \\
\hline 2012 & Filho [105] & & & & & $\checkmark$ & & & & $\checkmark$ & & & & & & & & \\
\hline 2012 & Fiore et al. [106] & & & & & $\checkmark$ & & & & $\checkmark$ & & & & & & & & \\
\hline 2012 & Millet et al. [107] & & & & & & & & $\checkmark$ & & & $\checkmark$ & & & & & & \\
\hline 2012 & Nakamura et al. [108] & & & & & & & & & & & & & & & & & $\checkmark$ \\
\hline 2012 & Santini et al. [109] & & & & & $\checkmark$ & & & $\checkmark$ & & & & & & & & & \\
\hline 2012 & Cheng et al. [110] & & & & & $\checkmark$ & & & $\checkmark$ & & & & & & & & & \\
\hline 2012 & Hatayama et al. [111] & & & & & & & & $\checkmark$ & & & & & & & & & \\
\hline 2012 & Wang and Chen [112] & & & & & & & & & & & & & & & $\checkmark$ & & \\
\hline 2012 & $\begin{array}{l}\text { Simic and Dimitrijevic [113, } \\
\text { 114] }\end{array}$ & & & & & & & $\checkmark$ & & & & & & & & & & \\
\hline 2013 & Arena et al. [115] & & & & & $\checkmark$ & & & & & & & & & & & & \\
\hline 2013 & Simic and Dimitrijevic [116] & & & & & & & $\checkmark$ & & & & & & & & & & \\
\hline 2013 & Simic and Dimitrijevic [117] & & & & $\checkmark$ & & & & & & & & & & & & & \\
\hline 2013 & Berzi et al. $[118]$ & & & & & & & & & $\checkmark$ & & $\checkmark$ & & & & & & \\
\hline 2013 & Tasala Gradin et al. [119] & & & & & $\checkmark$ & & & & & & & & & & & & \\
\hline 2013 & Saavedra et al. [120] & & & & & $\checkmark$ & & & $\checkmark$ & & & & & & & & & \\
\hline 2013 & Schmid et al. [121] & & & & & & & & $\checkmark$ & & & & & & & & & \\
\hline 2013 & Hu and Kurasaka [122] & & $\checkmark$ & & & & & & & & & & & & & & & \\
\hline 2014 & Miller et al. [123] & $\checkmark$ & & & & & & & $\checkmark$ & & & & & & & & & \\
\hline
\end{tabular}


Table 2 (continued)

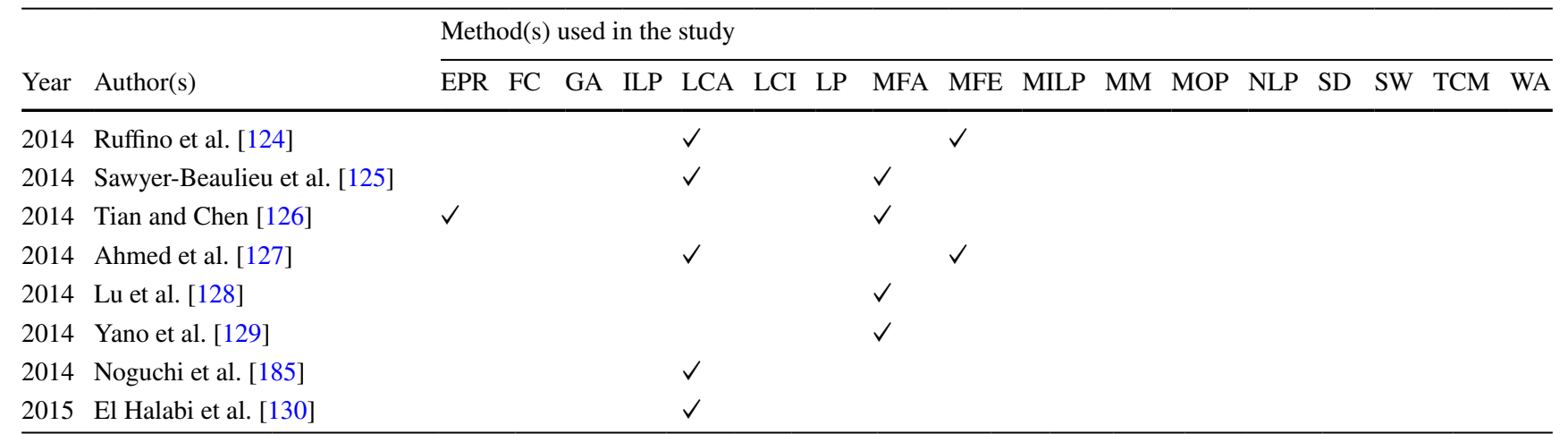

\begin{tabular}{|c|c|c|c|c|c|c|c|c|c|c|c|c|c|c|c|c|c|c|c|}
\hline \multirow[t]{2}{*}{ Year } & \multirow[t]{2}{*}{ Author(s) } & \multicolumn{18}{|c|}{ Method(s) used in the study } \\
\hline & & AHP & ANN & CBA & DEM & EFA & EA & FAHP & $\mathrm{FC}$ & FV & ILP & IOT & LCA & LCI & MFA & SD & SEM & TP & WA \\
\hline 2015 & $\begin{array}{l}\text { Chen et al. } \\
\text { [131] }\end{array}$ & & & $\checkmark$ & & & & & & & & & & & & & & & \\
\hline 2015 & $\begin{array}{l}\text { Despeisse } \\
\text { et al. [132] }\end{array}$ & & & & & & & & & & & & $\checkmark$ & & $\checkmark$ & & & & \\
\hline 2015 & $\begin{array}{l}\text { Ohno et al. } \\
\text { [133] }\end{array}$ & & & & & & & & & & & & & & $\checkmark$ & & & & $\checkmark$ \\
\hline 2015 & $\begin{array}{l}\text { Sawyer-Beaul- } \\
\text { ieu and Tam } \\
{[134]}\end{array}$ & & & & & & & & & & & & $\checkmark$ & $\checkmark$ & & & & & \\
\hline 2015 & $\begin{array}{l}\text { Yi and Park } \\
\text { [135] }\end{array}$ & & & & & & & & & & & $\checkmark$ & & & & & & & \\
\hline 2015 & $\begin{array}{l}\text { Simic and } \\
\text { Dimitrijevic } \\
{[136]}\end{array}$ & & & & & & & & & & $\checkmark$ & & & & & & & & \\
\hline 2015 & $\begin{array}{l}\text { Oguchi and } \\
\text { Fuse [137] }\end{array}$ & & & & & & & & $\checkmark$ & & & & & & & & & & \\
\hline 2015 & $\begin{array}{l}\text { Daniell et al. } \\
\text { [186] }\end{array}$ & & & & & & & & & & & & $\checkmark$ & & & & & & \\
\hline 2016 & $\begin{array}{l}\text { Belboom et al. } \\
\text { [138] }\end{array}$ & & & & & & & & & & & & $\checkmark$ & & & & & & \\
\hline 2016 & $\begin{array}{l}\text { Desnica et al. } \\
\text { [139] }\end{array}$ & $\checkmark$ & & & & & & & & & & & & & & & & & \\
\hline 2016 & $\begin{array}{l}\text { Inghels et al. } \\
\text { [140] }\end{array}$ & & & & & & & & & & & & $\checkmark$ & & & $\checkmark$ & & & \\
\hline 2016 & $\begin{array}{c}\text { Junior et al. } \\
\text { [141] }\end{array}$ & & & & & & & & & & & & $\checkmark$ & & $\checkmark$ & & & & \\
\hline 2016 & $\begin{array}{l}\text { Pan and } \mathrm{Li} \\
\text { [142] }\end{array}$ & & & & & & $\checkmark$ & & & & & & & & $\checkmark$ & & & & \\
\hline 2016 & $\begin{array}{c}\text { Ahmed et al. } \\
{[143,144]}\end{array}$ & & & & $\checkmark$ & & & $\checkmark$ & & & & & & & & & & & \\
\hline 2016 & $\begin{array}{l}\text { Pourjavad and } \\
\text { Mayorga } \\
{[145,146]}\end{array}$ & & & & & & & $\checkmark$ & & & & & & & & & & $\checkmark$ & \\
\hline 2016 & $\begin{array}{l}\text { Raja Mamat } \\
\text { et al. [147] }\end{array}$ & & & & & $\checkmark$ & & & & & & & & & & & $\checkmark$ & & \\
\hline 2016 & Li et al. [148] & & & & & & & & & & & & $\checkmark$ & & & & & & \\
\hline 2016 & $\begin{array}{l}\text { Tian and Chen } \\
\text { [149] }\end{array}$ & & & $\checkmark$ & & & & $\checkmark$ & & & & & & & & & & & \\
\hline 2016 & Xia et al. [150] & & & $\checkmark$ & & & & & & & & & & & & & & & \\
\hline 2016 & $\begin{array}{l}\text { Zhou et al. } \\
\text { [151] }\end{array}$ & & & & & & & & & $\checkmark$ & & & & & & & & & \\
\hline
\end{tabular}


Table 2 (continued)

Year Author(s)

Method(s) used in the study

$$
\text { AHP }
$$

ANN CBA

2016 Diener and

Tillman

[152]

$2016 \mathrm{Xu}$ et al. [153]

2016 Yano et al. [154]

2016 Fujimori et al. [188]

2016 Ericson et al. [189]

2017 Andersson et al. [155]

2017 Ene and Öztürk [156]

2017 Gan and Luo [157]

2017 Karaeen et al. [158]

2017 Soo et al. [159]

2017 Soo et al. [160]

2017 Nakano and Shibahara [161]

2017 Endo and Fuse [162]

2017 Miskolczi et al. [173]

2018 Khodier et al. [163]

2018 Zhang and Chen [164, 168]

2018 Hao et al. [165]

Method(s) used in the study

\begin{tabular}{|c|c|c|c|c|c|c|c|c|c|c|c|c|c|c|c|}
\hline Year & Author(s) & $\mathrm{ABC}$ & AHP & DEA & FA & FGDM & LCA & $\mathrm{LCC}$ & MBM & MFA & MILP & MM & SD & SW & $\mathrm{TP}$ \\
\hline 2018 & Mohan and Amit [166] & & & & & & & & & & & & $\checkmark$ & & \\
\hline 2018 & Raja Mamat et al. [5] & & $\checkmark$ & & & & & & & & & & & & \\
\hline 2018 & Rosa and Terzi [167] & & & & & & & & & & & & $\checkmark$ & & \\
\hline 2018 & Wong et al. [169] & & & & & & $\checkmark$ & & & & & & & & \\
\hline 2018 & Ortego et al. [170] & & & & & & & & & & & $\checkmark$ & & & \\
\hline 2018 & Lin et al. [171] & $\checkmark$ & & & & & & & & & $\checkmark$ & & & & \\
\hline 2018 & Gottesfeld et al. [183] & & & & & & $\checkmark$ & & & & & & & & \\
\hline 2018 & Ericson et al. [184] & & & & & & $\checkmark$ & & & & & & & & \\
\hline 2018 & Eguchi et al. [187] & & & & & & $\checkmark$ & & & & & & & & \\
\hline 2018 & Xu et al. [172] & & & & & & & & & $\checkmark$ & & & & & \\
\hline 2019 & Sato et al. [174] & & & & & & $\checkmark$ & & & & & & & & \\
\hline 2019 & Arora et al. [175] & & & & & & & & & & & & & $\checkmark$ & \\
\hline 2019 & Mohamad-Ali et al. [176] & & & & $\checkmark$ & & & & & & & & & & \\
\hline
\end{tabular}


Table 2 (continued)

\begin{tabular}{|c|c|c|c|c|c|c|c|c|c|c|c|c|c|c|c|}
\hline \multirow[b]{2}{*}{ Year } & \multirow[b]{2}{*}{ Author(s) } & \multicolumn{14}{|c|}{ Method(s) used in the study } \\
\hline & & $\mathrm{ABC}$ & AHP & DEA & FA & FGDM & LCA & $\mathrm{LCC}$ & MBM & MFA & MILP & MM & SD & SW & TP \\
\hline 2019 & Qiao et al. [177] & & & & & & & $\checkmark$ & & & & $\checkmark$ & & & \\
\hline 2019 & Wang et al. [178] & & & $\checkmark$ & & & & & & & & & & & $\checkmark$ \\
\hline 2019 & Yang et al. [179] & & & & & $\checkmark$ & & & & & & & & & \\
\hline 2019 & Yano et al. [180] & & & & & & & & $\checkmark$ & $\checkmark$ & & & & & \\
\hline
\end{tabular}

\section{Recycling, production and planning}

Being a strategic and a tactical issue to deal with for companies and governments, there are a significant number of studies focusing on the process and material analyses, product design, production and recycling planning.

Kirkpatrick et al. [32] investigated the environmental impacts of ELV disposal in the UK. Bellman and Khare [33] attempted to analyze financial sources of the ELV management and suggested a few policies about producer responsibility. Hartman et al. [34] presented a project to develop and demonstrate a method and the business potential in re-using components from ELVs. Díaz and Fernández [35] defined future treatment centers for ELV processing. Mark et al. [36] presented a demanufacturing chain under different scenarios to do economic analyses for vehicle instrument panels. Johnson and Wang [37] presented a demanufacturing optimization model to evaluate economics and material destinations within the requirements of the new ELV legislation. Petrov [38] developed a concept for an ELV recycling system for a Russian automotive company.

Johnson and Wang [39] presented an analysis tool that uses demanufacturing optimization to evaluate the economics and material destinations. Van Schaik et al. [40] proposed a dynamic optimization model for recycling aluminum from passenger vehicles. Boon et al. [41] proposed a model to assess the materials streams and process profitability for several clean vehicles via Goal programming. Petrov [42] researched recyclability of all basic LADA family automobiles to meet European ecological requirements. Castro et al. [43] performed the Life cycle impact assessment of the average passenger vehicles of the Netherlands, with emphasis on the current dismantling and recycling practices.

Gesing [44] reviewed current and future recycling technologies with a focus on increasing light material content. Mark and Kamprath [45] summarized various bonding applications and their materials aspect for vehicle lightweighting. Van Schaik and Reuter [46] developed dynamic modeling and simulation approaches to illustrate the influence of various parameters on the recycling rate. Van Schaik et al. [47] proposed a nonlinear optimization model to describe the relationship between particle size reduction and liberation during the shredding and recycling of ELVs. Kim et al.
[48] surveyed using some questionnaires processing rates and management status in Korea to aid the establishment of ELV management policies. Schmidt et al. [49] aimed at identifying the environmental impacts and relevance for combinations of recycling/recovery and lightweight vehicle design options over the whole life cycle. Pelletiere and Reinert [50] presented a database on used automobile protection, and employed gravity models of the used automobile trade. Bandivadekar et al. [51] presented a simulation model for material flows and economic exchanges to examine the effect of future changes in vehicle material compositions on the US recycling infrastructure.

Sawyer-Beaulieu and Tam [52] used Life-cycle assessment (LCA) to increase the understanding of and consequently improve the ELV management process in North America. Seo et al. [53] published a study about the ELV management and ASR characterization in Korea. Choi et al. [54] presented a mixed-integer programming model for tactical process planning in the case of traditional US automotive shredders. Castro et al. [55] presented a simulation model that describes the relationships between product design and the liberation level attained by the shredding of passenger seats. Forslind [56] analyzed the consequences of implementing EPR for vehicle recyclers in Sweden.

Chen [57] conducted a study to address the sustainable recycling of Chinese automobile products within the period of 2006-2010. Ferrao et al. [58] assessed the influence of the ELV Directive on the profitability of vehicle dismantlers and shredders. Krinke et al. [59] compared the environmental profiles of two different ELV recycling methods. Reuter et al. [60] explored the limits of ELV recycling. Forton et al. [61] emphasized current issues and drivers at play on the ELV management in the UK to outline their actual effects on present practice. Finkbeiner et al. [62] expressed the use of LCA on Mercedes-Benz S-Class vehicles. Mazzanti and Zoboli [63] addressed the ways specific to economic instruments reflecting the producer responsibility principle in waste and recycling policy. Amaral et al. [64] discussed how far recycling technology innovation can be a major driver for technology shift in the automobile industry. Ferrao and Amaral [65] developed technical cost models to assess the economics of dismantling and shredding activities. Pelletiere and 
Reinert [66] modeled the used automobile exports of Japan and the USA using two alternative gravity models.

Coates and Rahimifard [67] provided an overview of the stakeholders and their relationships within the UK recovery chain and discussed the development of an ELV costing framework. Jeong et al. [68] focused on the ELV treatment system in Korea using LCA methodology to evaluate its environmental performance and identify potential improvement opportunities. Joung et al. [69] investigated the recycling rate and management status to aid the establishment of a policy for the ELV management in Korea. Mergias et al. [70] used the PROMETHEE method to select the best compromise scheme for the ELV management in Cyprus. Dalmijn and De Jong [71] analyzed the development of the vehicle recycling industry in the EU. Giannouli et al. [72] developed a methodology and technical model for the evaluation of waste produced from road vehicles. Sakai et al. [73] investigated the unintentional formation, decomposition, and emission-control performance of POPs during ASR incineration. Williams et al. [74] proposed a MILP model for making tactical decisions regarding what extent to process and reprocess materials. Alonso et al. [75] published a research project to contribute cost-effective and eco-efficient electrical and electronic systems components in the automotive industry. Frad and Revnic [76] presented a method to assure the achievement of the required eco-efficiency rates, integrated into the software tool for car manufacturing. Ribeiro et al. [77] modified a multi-material car component which is a part of the current automotive brake system, by its original manufacturer. Fuse et al. [78] quantified the outflow of base metals indirectly exported from Japan in the form of ELVs.

Ignatenko et al. [79] extended the optimization model proposed by Reuter et al. [60] to add thermal treatment processes and energy recovery constraints. Qi and Hongcheng [80] proposed a MILP model for designing an ELV recovery network constituted from dismantling centers and processing facilities. Sawyer-Beaulieu and Tam [81] used LCA to analyze ELV dismantling and shredding processes. Smith and Keoleian [82] investigated the energy savings and pollution prevention in the US through remanufacturing a midsized automotive gasoline engine. Fuse and Kashima [83] developed an automobile recycling input-output analysis-based evaluation method to examine the appropriateness of the recycling scheme for ELVs imported from Japan. Qu and Williams [84] formulated automotive reverse production planning and pricing problems in a nonlinear programming model to develop an approximate supply function for hulks.

Chondros [85] reviewed ELV treatment alternatives to ease the creation of an efficient ELV management system in different local conditions. Puri et al. [86] stimulated material alternatives and end-of-life strategies for automotive components. Amelia et al. [87] identified the existing conditions of automotive reuse in Malaysia by conducting interviews in selected local automotive and component manufacturers. Chen and Zhang [88] provided insight into current thinking within China about the ELV management as well as vehicle recovery activities. Kumar and Sutherland [89] focused on certain profit-enhancement strategies that may be employed to ensure the economic sustainability of ELVs. Fuse et al. [90] proposed an estimation method for calculating the number of used passenger cars employed in world trade. Differently, Fuse et al. [91] used the regression analysis to estimate the global flow of base metals (iron, aluminum, copper, lead, and zinc) in the used automobile trade.

Santini et al. [92] studied the impact that pre-shredder treatment could have on achieving $85 \%$ recyclability rate in 2015. Chen et al. [93] thoroughly described the principles and characteristics of the vehicle recycling system in Taiwan. Go et al. [94] provided a framework for automotive components to be designed for ease of recovery by optimizing the disassembly sequence. Mathieux and Brissaud [95] presented a new method to elaborate end-of-life productspecific material flow analysis, based on data obtained from statistics as well as from expert elicitation.

Agbo [96] quantified the available salvage value and service materials potential from imported used vehicles in Nigeria. Duranceau and Sawyer-Beaulieu [97] determined and quantified today's actual ELV disposition rates based on their age and material content. Hedayati and Subic [98] proposed a decision-making support framework for the recovery of ELVs to provide an integrated sustainable treatment option. Kibira and Jain [99] studied the impact of hybrid and electric vehicles on the profitability of the recycling infrastructure. Santini et al. [100] reported a shredder campaign trial developed and performed in Italy at the beginning of 2008. Xi et al. [101] proposed a new method for predicting the residual strength and life of reused components or parts of ELVs. Zoraga et al. [102] calculated energy consumption and carbon dioxide emissions of ELV recycling. Che et al. [103] presented the ELV recycling system of Japan, China and Korea and in developing countries as well. Nazmi et al. [104] suggested an ANN-based tool for predicting the critical stress life of a vehicle door with focusing on the optimal reusability.

Filho [105] analyzed the various constituent vehicle materials and their impact on the environment in Brazil. Fiore et al. [106] presented a characterization and valorization study about ASR in Italy. Millet et al. [107] proposed a method based on an impact module on recycling rate indicators for identifying the worst recycling case. Nakamura et al. [108] presented a novel approach to quantifying quality and dilution losses through hybrid input-output analysis. Santini et al. [109] investigated ASR pre-treatment and pyrolysis to determine whether the ELV recycling target could be achieved by car fluff mechanical separation. Cheng et al. [110] introduced a preliminary approach to examine 
the operational characteristics of the ELV recycling business in Taiwan. Hatayama et al. [111] discussed how the recycling of aluminum will change until 2050, focusing on the introduction of next-generation vehicles and scrap sorting technology. Wang and Chen [112] analyzed the current ELV recycling system in China and introduced an automotive product recycling technology roadmap. Simic and Dimitrijevic [113] expanded the linear programming modeling framework proposed by Simic and Dimitrijevic [114] to incorporate the vehicle hulk selection problem. Simic and Dimitrijevic [114] presented a tactical production planning problem for vehicle recycling factories in the EU legislative and global business environments.

Arena et al. [115] developed a performance measurement system to help automotive manufacturers to assess their technological options for sustainable mobility. Simic and Dimitrijevic [116] proposed a short-term ASR recycling planning model for the Japanese vehicle recycling industry. Simic and Dimitrijevic [117] developed a risk explicit MINP model for optimal long-term planning in the EU vehicle recycling facilities. Berzi et al. [118] built a process simulation model that could be used for layout planning of ELV dismantling facilities. Tasala Gradin et al. [119] applied the LCA method to compare two waste management scenarios: manual disassembly and shredding. Saavedra et al. [120] presented an exploratory study on the current remanufacturing scenario and its main characteristics within the Brazilian automotive sector. Schmid et al. [121] present the results from the quantitative and qualitative characterization of different material flows resulting from the three experimental campaigns on an industrial site. Hu and Kurasaka [122] developed a projection model for ELV distribution per population at the provincial level in China.

Miller et al. [123] examined the challenges of plastics recycling in the North American automotive industry. Ruffino et al. [124] performed an economic assessment of a hypothetical industrial recovery process of light ASR, obtained by transferring the results gathered at lab scale to full scale. Sawyer-Beaulieu et al. [125] presented strategies and actions for decreasing the lifecycle impact of automobiles. Tian and Chen [126] illustrate the difficulty of handling polymers from a vehicle dashboard. Ahmed et al. [127] examined the current state of the ELV management in Malaysia. Lu et al. [128] identified drivers for new joining solutions in the automotive industry and specifically reviewed the current use of adhesive technology in ELVs. Yano et al. [129] investigated the dynamic substance flow of lead as a representative toxic substance in ELVs and ASR. They applied a population balance model for estimating the number of generated ELVs in Japan between fiscal years 1990-2020.

El Halabi et al. [130] assessed the environmental impact of using a multi-dismantling machine for material separation. Chen et al. [131] applied dynamic modeling and cost-benefit analysis to investigate how policies may affect the recycling of ELVs in China. Despeisse et al. [132] proposed policy, technical and business recommendations to improve reuse, recycling, and recovery rates. Ohno et al. [133] used a waste input-output material flow analysis to investigate the content of alloying elements in ELVs. Sawyer-Beaulieu and Tam [134] discussed the challenges anticipated with the development of ELV management systems. Yi and Park [135] developed a smart dismantling monitoring and smart trolley system for an ELV recycling center. Simic and Dimitrijevic [136] formulated and comprehensively tested a model for optimal long-term planning of vehicle recycling in the Republic of Serbia. The lifespan of a vehicle determines the amount of end-of-life flows. Oguchi and Fuse [137] proposed a straightforward method for estimating the lifespan distribution of passenger cars based on the age profile of in-use cars.

Belboom et al. [138] undertook an environmental evaluation of hybrid vehicles recycling using industrial data from Comet Traitement SA in Belgium. Desnica et al. [139] presented an AHP approach to select equipment for detoxification of ELVs. Inghels et al. [140] assessed the influence of material composition, amount and lifespan of passenger cars on the ELV management in Belgium. Junior et al. [141] addressed vehicle recycling processes and manufacturer responsibility around the globe and the benefits to the economy, society, and environment. Pan and Li [142] employed an improved emergy analysis with traditional and revised emergy indices for evaluation of the efficiency and sustainability of ELV recycling enterprises. Ahmed et al. [143, 144] used DEMATEL and extent analysis method on the fuzzy AHP to rank ELV management alternatives concerning several sustainable criteria. Pourjavad and Mayorga [145] also proposed an integrated fuzzy DM framework to evaluate sustainable ELV strategies. Pourjavad and Mayorga [146] coupled the fuzzy AHP and fuzzy TOPSIS methods to rank seven ELV management strategies. Raja Mamat et al. [147] develop a framework for the ELV management in Malaysia. Li et al. [148] evaluated the environmental impacts of ELV recycling processes in China. Tian and Chen [149] used the fuzzy AHP technique and cost-benefit analysis to compare five manual dismantling scenarios in China. Xia et al. [150] applied cost-benefit analysis to perform the construction and investment analysis of an ELV disassembly plant in China. Zhou et al. [151] developed a multi-criteria model based on the fuzzy VIKOR technique to evaluate ELV recycling service providers from the perspective of sustainability. Diener and Tillman [152] examined the case of an automotive component manufacturer to investigate its ELV management. Xu et al. [153] conducted a scenario analysis to determine the amount of rare earth elements that can be recovered from ELVs in Japan based on a dismantling survey, chemical 
identification, and substance flow analysis. Yano et al. [154] used a population balance model for estimating the number of end-of-life hybrid electric vehicles generated in Japan during fiscal years 2010-2030. Besides, the amounts of rare earth elements contained in a hybrid transmission and a NiMH battery unit were presented.

Andersson et al. [155] utilized the technological innovation system framework to identify key functions from 1910 to 2010 that enabled ELV iron recycling in Sweden. Ene and Öztürk [156] developed an approach for predicting the number of ELVs that will be generated in the future. Gan and Luo [157] presented a fuzzy-based DEMATEL approach to identify critical factors influencing the recycling rate of ELVs. Karaeen et al. [158] presented a concept for the second life cycle of vehicles. Soo et al. [159] discussed a comparative study on the environmental performance of the current ELV recycling processes between Australia and Belgium. Soo et al. [160] analyzed the joining technologies used in the automotive industry to identify the ELV recyclability. Nakano and Shibahara [161] used the LCA method for quantifying the amounts of greenhouse gases emitted when recycling ELVs by using the traditional shredding approach and the whole recycling approach, in which ELVs are pressed and transferred to an electric furnace or converter. Endo and Fuse [162] explored and reduced the uncertainty in international trade for used automobiles and engines by correcting outliers and missing values.

Khodier et al. [163] focused on challenges around ASR processing and disposal in the UK. Zhang and Chen [164] used the AHP method to compare four ELV dismantling planning scenarios. Hao et al. [165] aimed to better manage the reverse supply chain of the automotive industry in the context of green, circular, and sustainable development. Mohan and Amit [166] proposed a system dynamics model to analyze informal dismantling facilities in India, which operate like a perfectly competitive market. Raja Mamat et al. [5] proposed a performance evaluation tool based on the Analytic Hierarchy Process for implementation, monitoring and continuous improvement of the Malaysian ELV management system. Rosa and Terzi [167] evaluated the current economic performances of the Italian ELV recovery chain using the system dynamics simulation approach. Zhang and Chen [168] constructed an Arena-based simulation tool to analyze four scenarios of an ELV disassembly line in China. Wong et al. [169] proposed a new concept of a processing framework to utilize ELV waste to construction industries via a new trend of circular economy applications in Malaysia. Ortego et al. [170] proposed a downcycling assessment methodology based on the thermodynamic rarity indicator for accounting quantity and quality of the materials lost in the ELV recycling process. Lin et al. [171] used a population balance model for predicting the number of generated ELVs in Kinmen, Taiwan, in the period 1960-2050.
They presented material flow and economic analyses of a dismantling business in small islands. Xu et al. [172] performed a scenario analysis to determine the amount of five precious metals that could be returned to material streams from ELVs based on the dismantling survey, chemical identification, and substance flow analysis. Also, a population balance model was utilized for forecasting the number of generated ELVs in Japan in the period 2015-2040.

Miskolczi et al. [173] proposed a study about the modification of zeolite catalysts by metal loading for using ELV plastic waste pyrolysis. Sato et al. [174] proposed an evaluation method to assess benefits with enabling energy consumption and carbon dioxide emission. Arora et al. [175] attempted to use the shared responsibility based framework to explore and develop a business model of the ELV management in India. Mohamad-Ali et al. [176] carried out a survey to identify the issues and factors of the ELV recovery system in Malaysia. Qiao et al. [177] presented a survey that focused on the economic and environmental benefits of electric vehicle recycling in China. Wang et al. [178] analyzed the efficiency of the ELV reverse logistics industry to improve resource utilization efficiency in Shanghai, China. Yang et al. [179] presented a systematic index system in selecting criteria for sustainable ELV management via constructing a group DM approach in a fuzzy environment. Yano et al. [180] conducted a dismantling survey and chemical analysis of six ELVs to estimate the content of valuable and toxic elements/substances.

Used lead-acid battery recycling is a growing hazardous industry. The lead issues from automotive battery recycling are major sources of soil contamination and human health exposure. The management of this hazardous waste from the ELV recycling process was mainly neglected in the previous reviews (Table 1). Hoffmann and Wilson [181] provided a brief characterization of the lead-acid battery recycling industry in the Philippines. Haefliger et al. [182] investigated a mass lead intoxication that occurred as a result of unsafe informal automotive lead-acid battery recycling in Dakar, Senegal. Gottesfeld et al. [183] assessed soil contamination inside and outside recycling plants operating with government approval to recycle used lead-acid batteries in seven African countries. Several studies investigated soil contamination and human health exposure in the battery recycling craft village, Dong Mai, Vietnam [184-188]. For instance, Ericson et al. [184] evaluated the efficiency of a novel soil lead mitigation project, Noguchi et al. [185], Daniell et al. [186], and Eguchi et al. [187] assessed human lead exposure, while Fujimori et al. [188] studied the lead contamination level in surface soil on roads. Ericson et al. [189] estimated the number of informal lead-acid battery recyclers and the number of exposed people in 90 low- and middle-income countries. 
The previous studies, related to recycling processes and analyses of materials, mostly suggested solutions for various local problems. More general and global approaches are highly needed. Moreover, material concepts and perceptions of the vehicles tend to change. Thus, more studies regarding this issue are needed in the future. Furthermore, most of the studies which are considering the managerial perspective are suggesting solutions about economic and/or material issues. There are not enough studies that include social criteria. The participation of the public is an important factor for the ELV management. Owners of ELVs need to be encouraged to withdraw their vehicles from the traffic. For this reason, social acceptance and social awareness are also important problems to deal with for more effective ELV management.

Although there are various types of product design and production planning studies about the ELV management, there are not enough studies comparing the designing and planning systems as before and after. Effects of recycling friendly product design and production planning could be monitored via customer feedbacks, financial analyses, etc.

Due to new ELV regulations, producers' responsibilities are gaining importance. Manufacturers are expected to make their designs and revise their production plans according to legislation. Herewith, there are several types of approaches studied by the researchers.

\section{Network design}

The recycling process of ELVs includes its own supply chain management problem. There are numerous studies in the literature which are suggesting approaches to cope with supply chain issues of the ELV management. Ahn et al. [190] created an optimization tool for solving facility location problems and developed a simulation tool for ELVs of the German automobile industry. Schultmann et al. [191] presented the peculiarities of establishing a closed-loop supply chain (CLSC) for ELVs. Mansour and Zarei [192] developed a multi-period reverse logistics optimization model to locate ELV collection centers and vehicle dismantlers. Cruz-Rivera and Ertel [193] constructed an uncapacitated facility location model to design a collection network for ELVs in Mexico.

Merkisz-Guranowska [194, 195] formulated MILP models to determine the optimum locations of the key participants of the ELV recycling network. Zarei et al. [196] designed a reverse logistics network for the management of the ELV recovery process. Harraz and Galal [197] presented a mixed-integer lexicographic goal programming for designing a sustainable recovery network for ELVs in Egypt. Mahmoudzadeh et al. [198] proposed a capacitated locationallocation model for determining locations of ELV collection points from the perspective of the third-party reverse logistics provider. Vidovic et al. [199] presented a modeling approach that could be used to locate collection points for ELVs.

Merkisz-Guranowska [200, 201] formulated a bi-objective mixed-integer linear programming model aiming at the reorganization and construction of the ELV recycling network in Poland. Farel et al. [202] used a MILP modeling technique to determine the optimal topology and material flow in future ELV glazing recycling network. Gołebiewski et al. [203] proposed a simulation approach that could be used to determine optimum locations for ELV dismantlers. Mahmoudzadeh et al. [204] used a MILP formulation to solve a location-allocation problem of ELVs scrap yards in Iran.

Ene and Öztürk [205] developed a model for managing reverse flows of ELVs within the framework of a multiperiod, multi-stage, capacity-constrained network design problem. Simic [206] developed a two-stage interval-stochastic programming model for supporting the management of ELV allocation under uncertainty. Simic [207] proposed a fuzzy risk explicit MINP model for ELV recycling planning in the EU. Subulan et al. [208] formulated a multi-objective, multi-echelon and multi-product mixed-integer linear programming model with fuzzy objectives for optimizing the lead-acid battery CLSC in Turkey.

Alsaadi and Franchetti [209] studied on finding the optimum location for a processing facility for ELVs. Demirel et al. [210] proposed a MILP model for reverse logistics network design including different actors taking part in the ELV recycling system. Simic [211] presented a multi-stage interval-stochastic programming model for planning ELV allocation. Simic [212] proposed an interval-parameter twostage stochastic full-infinite programming model for ELV allocation management under multiple uncertainties. Simic [4] developed an interval-parameter chance-constraint programming model for uncertainty-based decision-making in the ELV recycling industry under rigorous environmental regulations.

Phuc et al. [213] formulated a fuzzy MILP model for designing a multi-echelon, multi-product reverse logistics network. Özceylan et al. [214] presented a case study from Turkey based on CLSC for ELV treatment. Deng et al. [215] established a simulation-optimization model for the location, path and inventory problem of ELV recycling systems. Lin et al. [216] proposed a MILP model for the facility location-allocation problem of an ELV recovery network. Shankar et al. [217] formulated a MILP model for the CLSC network with a multi-echelon inventory, multi-period planning, and multi-product scenario. Sun et al. [218] developed a mixed-integer bilevel linear programming model to locate distribution centers for collecting ELV parts. The outer and inner optimization tasks were minimizing location costs and transportation costs, respectively. $\mathrm{Ma}$ and $\mathrm{Li}$ [219] proposed a two-stage stochastic programming model for solving the 
lead-acid battery CLSC problem with random demands and returns.

Kuşakc1 et al. [220] modeled the problem of designing the ELV reverse logistics network for the Istanbul Metropolitan area as a fuzzy mixed-integer linear program. Xiao et al. [221] developed a MILP model for constructing a fourtier reverse logistics network model, which included ELV sources, collection centers, remanufacturing centers, and dismantlers.

In addition, the publications including mathematical models were categorized based on the type of decision variables, optimization model and solution approach. They are summarized in Table 3.

Available investigations that are suggesting approaches to cope with supply chain issues of the ELV management are mostly performed with deterministic data. ELV management systems are complex waste management systems with many uncertain components. Uncertainties also exist with economic and technical parameters, ELV supply, etc. Moreover, most of the real-life applications involve highly complex uncertainty. Therefore, an extension of the available modeling frameworks to address uncertainties can provide a much more realistic representation of ELV management systems.

\section{Regulations review}

Several regulation analyses are made in the literature as legislations play an important role in the ELV management. Levizzari [222] addressed the impacts of the ELV Directive on the Italian automotive industry. Kanari et al. [223] analyzed the current situation and future of the ELV management in the EU. Sakkas and Manios [224] identified and evaluated investment strategies for the ELV management in Greece. Smith et al. [225] examined how the abandoned vehicle problem is likely to develop in the future with the introduction of new laws and initiatives.

Chen [226] reviewed the ELV policy, law and administration system in China. Marsh [227] reported a survey about recycling collaborative combats legislation threat. Nakajima and Vanderburg [228] described and analyzed the German ELV take-back system in terms of its impact on the environment and companies involved. Edwards et al. [229] presented a basis for future research by evaluating the potential direction of the recovery industry. Saman and Blount [230] provided a review of current practices in vehicle recycling in Europe, USA, Japan, and Australia together with an overview of legislation, stakeholders and corresponding markets.

Gerrard and Kandlikar [231] presented an evaluation framework based on anticipated changes that could result from the ELV Directive. Smink [232] evaluated the extent to which environmental regulations have been a driving force for change in the car-dismantling trade in Denmark.
Manomaivibool [233] explored the impacts of network management on the environmental effects of the programs for the ELV management in the UK and in Sweden from an EPR perspective. Smith and Crotty [234] examined the impact of the ELV Directive on vehicle component manufacturers in the UK using a questionnaire tool.

Konz [235] presented a survey to analyze the ELV Directive. Altay et al. [236] focused on the recycling of metal from ELVs in Turkey and its legislative relations with the Kyoto Protocol. Zhao and Chen [237] gave a brief introduction to ELV regulations in Japan and China. Wang and Chen [238] compared ELV legislation between China, EU, Japan, and Korea to improve the policy implementation on ELV recycling in China. Blume and Walther [239] examined the legislative influence on the German vehicle industry. Farel et al. [240] proposed a model to investigate the potential cost and benefit of the ELV glazing recycling network in France.

Table 4 presents the summary of regulations review publications in the literature.

Most of the studies in the scope of regulative analyses are mainly considering local case studies. However, regulations globally affect many countries in the world simultaneously.

\section{Discussion}

The ELV management is such a crucial issue to deal with for the actors like governments, producers, treatment facilities and users. Due to regulations and new legislation, it is becoming even more important both environmentally and economically. Apart from being an operational process, it is also a type of strategic and tactical level decision for decision-makers.

Figure 4 shows the distribution of studies per year between 2000 and 2019. Based on Fig. 4, 61.6\% of studies on the ELV management (143 out of 232) were published in the last nine years. Therefore, there is a significant increase in the number of publications in the area of the ELV management after the year 2011. Furthermore, Fig. 1 also presents that the production rate of passenger vehicles has had an upward trend simultaneously.

Figure 5 presents the quantity and percentage of studies based on their purpose. According to Fig. 5, the majority is in the scope of "Recycling, production and planning" category. Although the ELV management has a multidisciplinary concept, the lack of hybrid studies can be clearly identified.

Figure 6 provides the distribution of the studies based on the applied method. Based on Fig. 6, 32.08\% of studies in the scope of "Recycling, production and planning" on the ELV management (51 out of 159) applied the LCA method. It is possible to see that publications are not homogenous based on the method applied. As a multidisciplinary subject, there are many possible issues to deal 


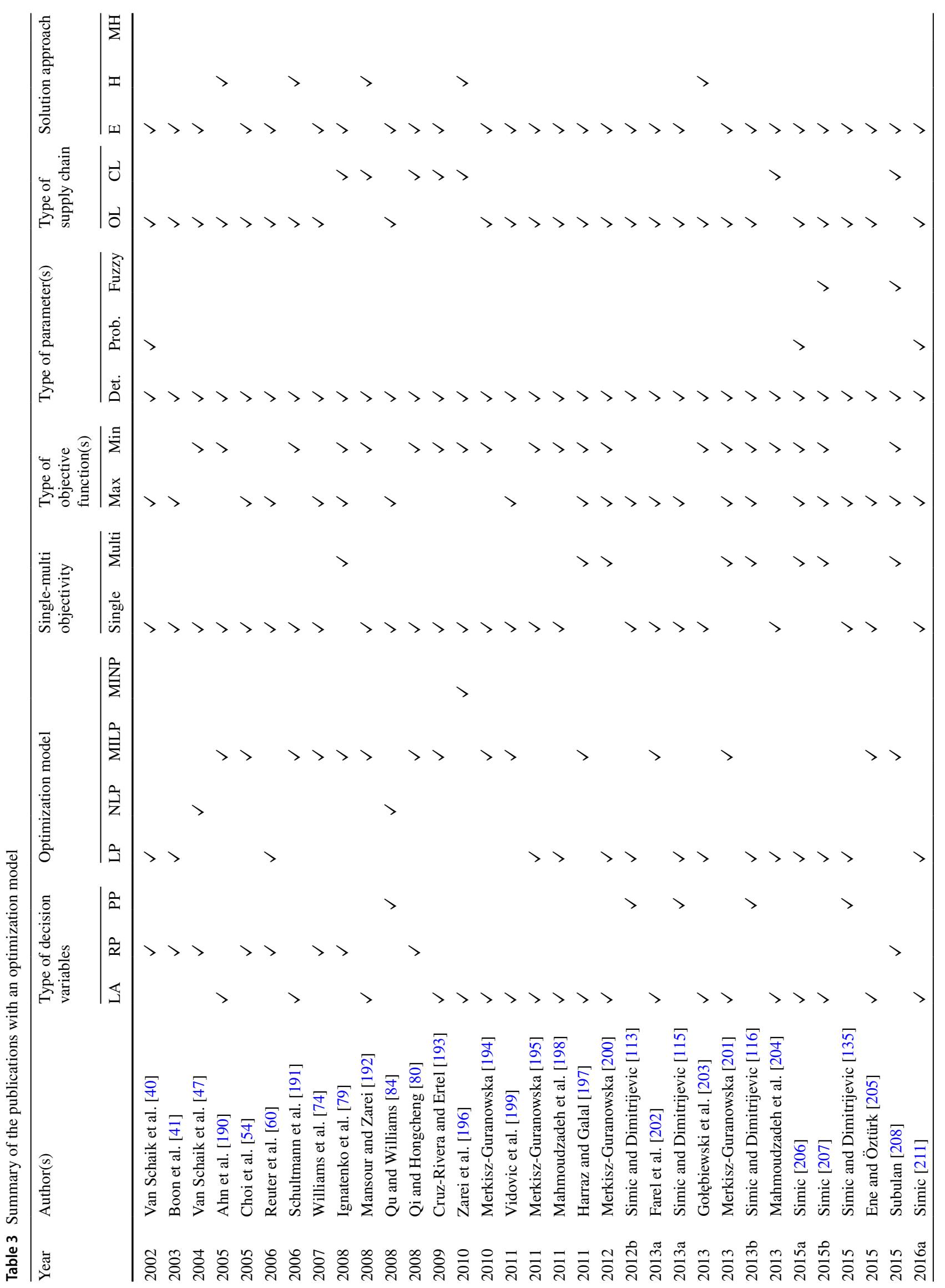




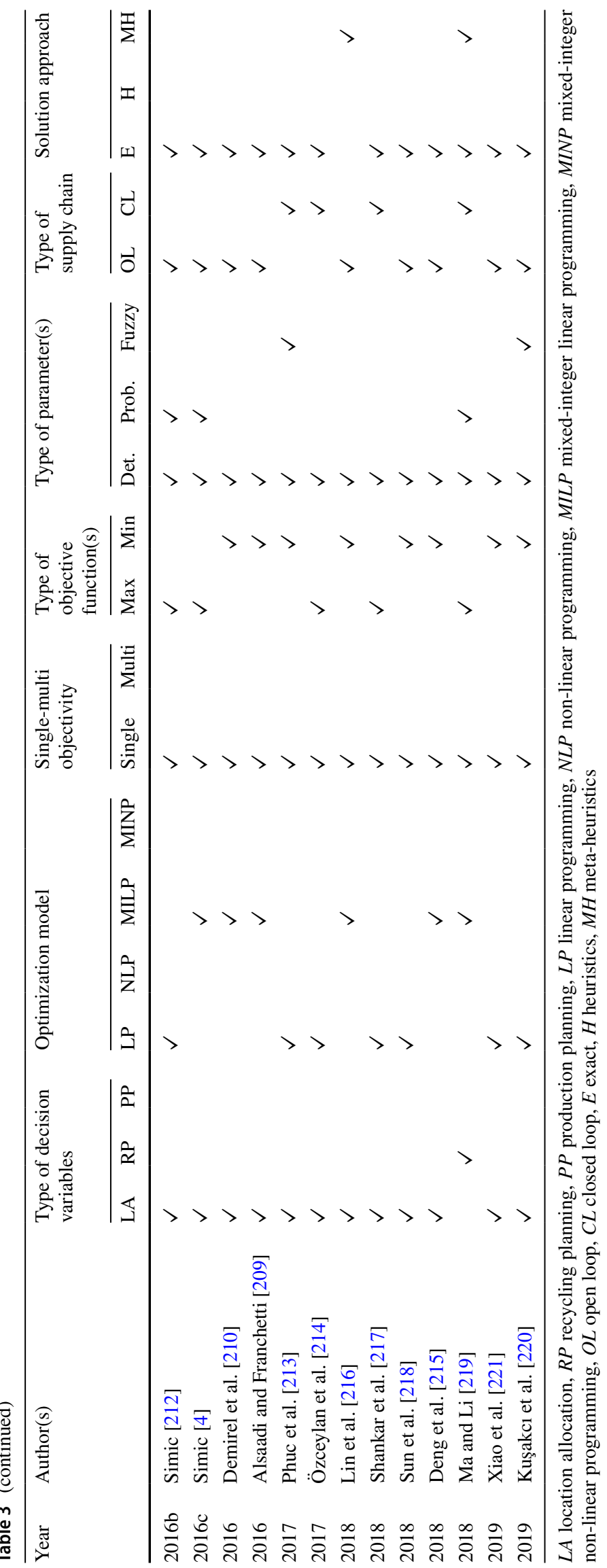


Table 4 Summary of regulations review publications on the ELV management

\begin{tabular}{ll}
\hline Author(s) and year & Research focus \\
\hline Levizzari (2002) [222] & Italy \\
Kanari et al. (2003) [223] & The European Union \\
Marsh (2005) [227] & \\
Gerrard and Kandlikar (2007) & \\
[231] & \\
Sakkas and Manios (2003) [224] & Greece \\
Smith et al. (2004) [225] & England and the United Kingdom \\
Edwards et al. (2006) [229] & \\
Smith and Crotty (2008) [234] & \\
Chen (2005) [226] & China \\
Wang and Chen (2013) [238] & \\
Nakajima and Vanderburg (2005) & Germany \\
[228] & \\
Blume and Walther (2013) [239] & \\
Saman and Blount (2006) [230] & The European Union, the USA, \\
Smink (2007) [232] & Japan, and Australia \\
Manomaivibool (2008) [233] & The United Kingdom and Sweden \\
Konz (2009) [235] & The USA \\
Altay et al. (2011) [236] & Turkey and Kyoto Protocol \\
Zhao and Chen (2011) [237] & China and Japan \\
Farel et al. (2013) [240] & France \\
\hline
\end{tabular}

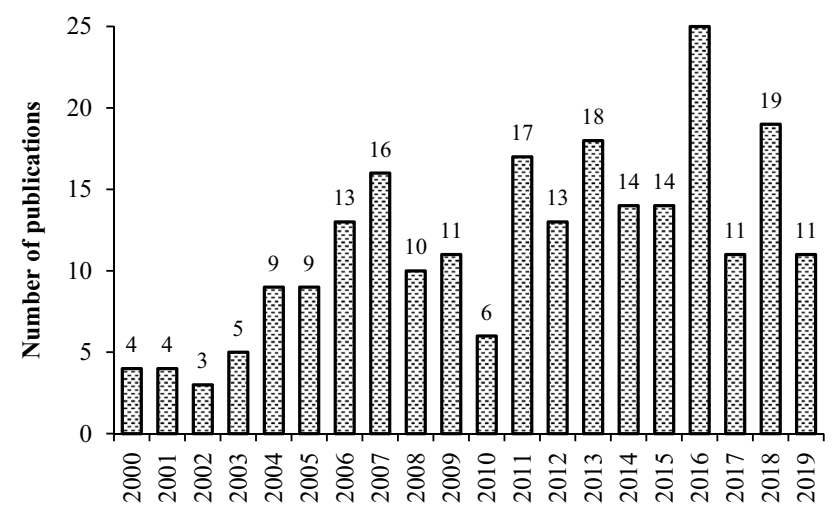

Fig. 4 Distribution of studies per year across the period 2000-2019

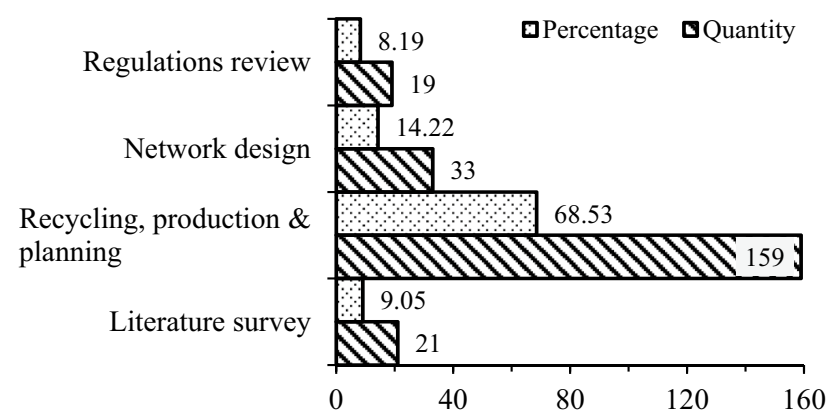

Fig. 5 ELV management studies based on their major classification

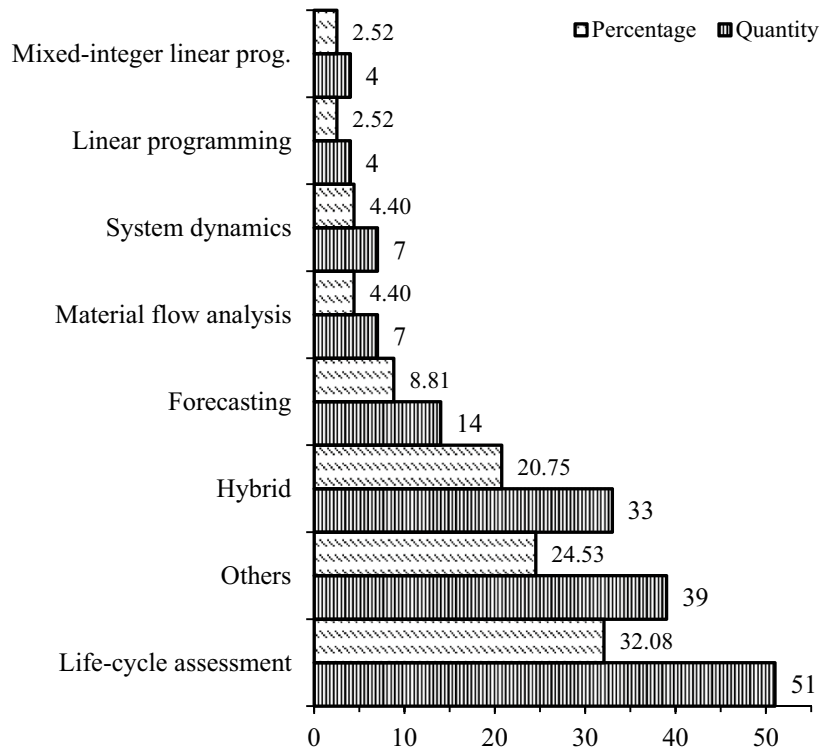

Fig. 6 Applied method

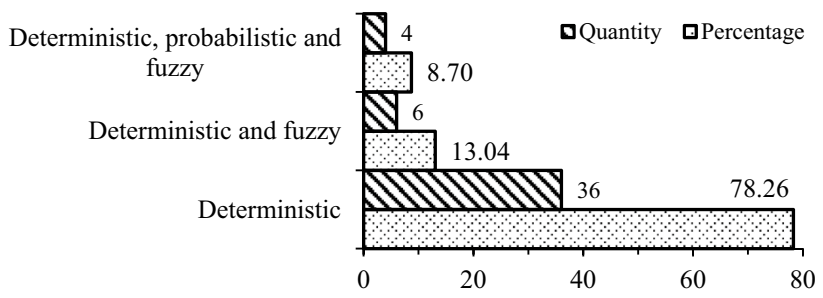

Fig. 7 Type of parameters

with while solving ELV management problems. In fact, new combinations in methodology may offer new solutions for real-life cases.

Figure 7 presents the percentage and quantity of the publications with a mathematical optimization model based on the type of parameters used in the analyzed studies. According to Fig. 7, the vast majority of researchers preferred to use deterministic parameters. It is not realistic to study with deterministic parameters for real-life cases. Therefore, new approaches with probabilistic and fuzzy parameters should be in the focus of future contributions.

Figure 8 shows the distribution of papers based on the studied type of supply chain network of ELVs and its components. Based on Fig. 8, 76.09\% of studies on the ELV management (35 out of 46) are dealing with open-loop supply chain problems. In fact, there is a lack of research suggesting a solution for both open- and closed-loop supply chains.

Figure 9 presents the number and percentage of the studies with a mathematical optimization model based on the type of decision variables. These studies mostly preferred to 


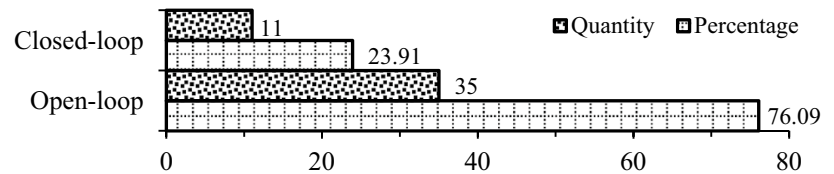

Fig. 8 Type of supply chain

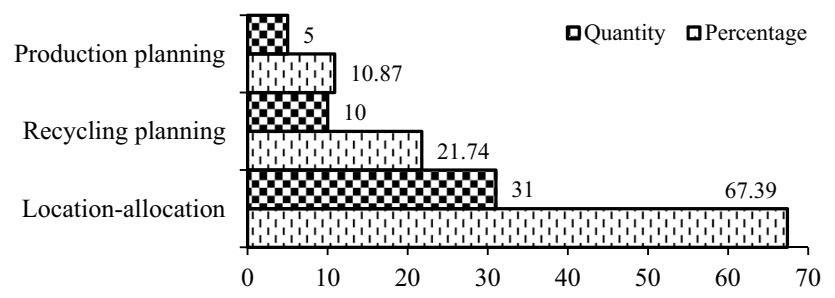

Fig. 9 Studies with a mathematical optimization model based on the type of decision variables

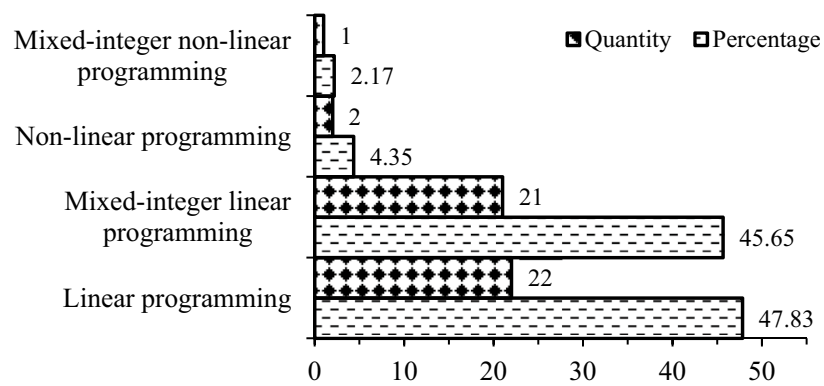

Fig. 10 Type of optimization model

deal with location-allocation problems (31 out of 46). There are not enough hybrid approaches in this field. Furthermore, studies in the scope of production and recycling planning are very limited.

Figure 10 presents the quantity and percentage of the collected studies based type of optimization model. From Fig. 10, it is evident that studies with a mathematical optimization model are mostly based on linear programming and MILP. Only 3 out of 46 studies developed non-linear optimization models.

Figures 11, 12 present distributions of studies with a mathematical optimization model based on single-multi objectivity and type of objective function, respectively. The lack of multi-objective approaches is more than evident; i.e., $82.61 \%$ for single-objective studies and $17.39 \%$ for multiobjective studies (Fig. 11). According to Fig. 12, both types of objective functions are considered in just $17.39 \%$ of the studies with a mathematical model. It should be mentioned that the majority of the studies with a mathematical model considered cost as its objective function (Fig. 12). There are

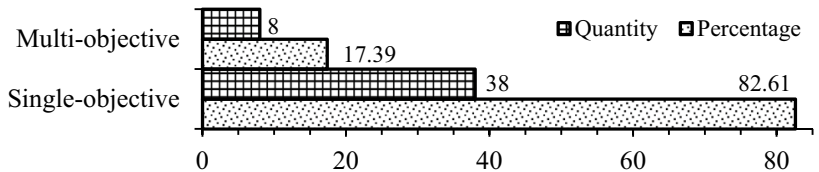

Fig. 11 Studies with a mathematical optimization model based on single-multi objectivity

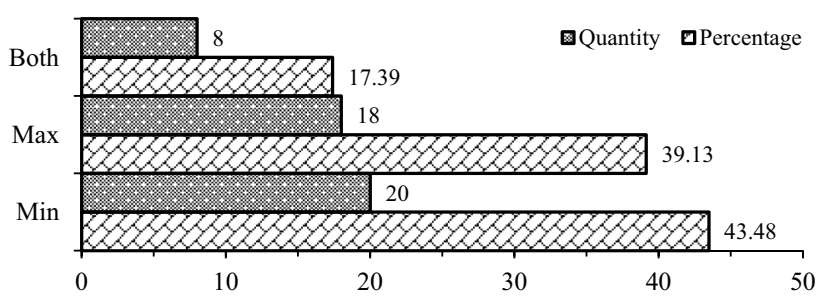

Fig. 12 Studies with a mathematical optimization model based on the type of objective function

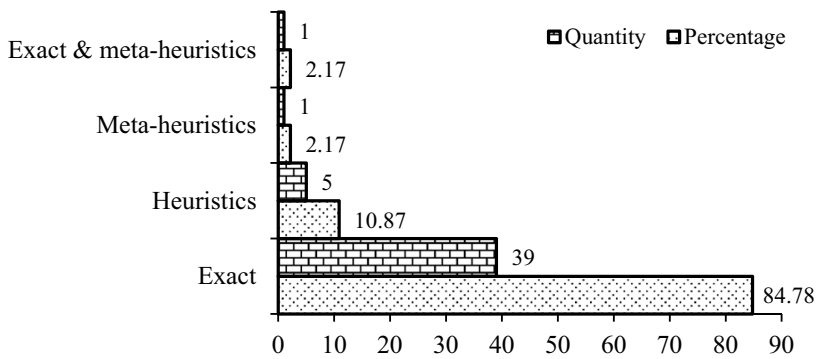

Fig. 13 Studies with a mathematical model based on the solution approach

other objective targets either conflicting or non-conflicting to optimize in the ELV management models.

Figure 13 presents the quantity and percentage of studies with a mathematical model based on the solution approach. It indicates that the vast majority of the approaches offered exact solutions instead of heuristics and meta-heuristics since most of them deal with either small or medium-size cases. Real-life ELV management problems usually need inexact colution approaches for generating reasonable solutions.

The distribution of studies on the ELV management based on the source of publication is presented in Table 5 . The journals with five or more publications are provided in the table. The primary publication outlets for the ELV management research area are: Journal of Cleaner Production (12.07\% share), Resources, Conservation and Recycling (10.78\% share), Journal of Material Cycles and Waste Management (7.76\% share), and Waste Management (7.76\% share), jointly publishing $38.4 \%$ of the total number of studies on the ELV management printed in the period 


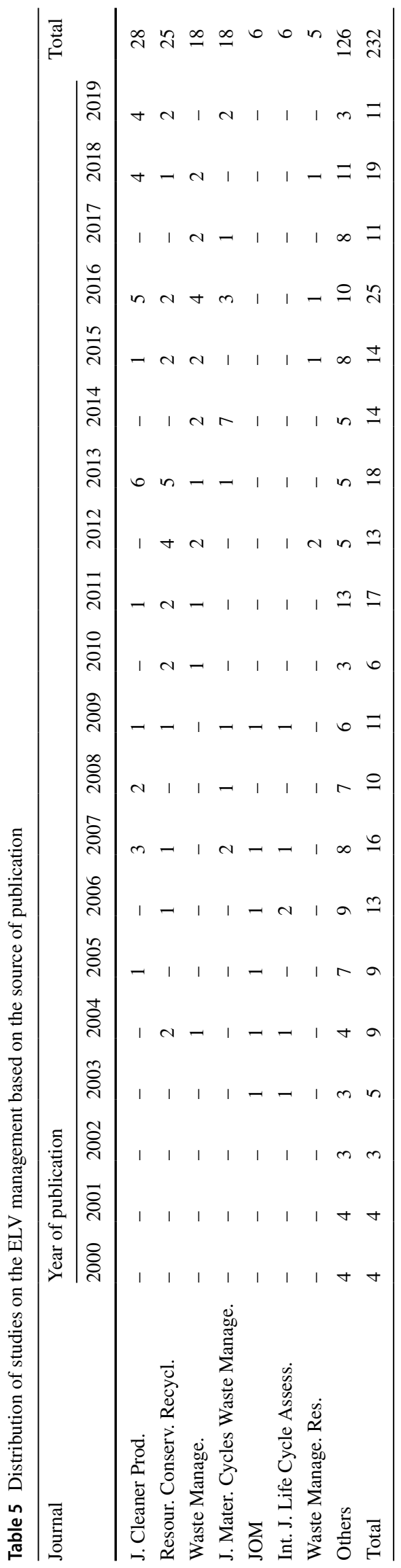

2000-2019. Moreover, these four journals published almost $47 \%$ of the total identified number of studies in the past five years. On the other hand, the secondary publication outlets for the explored research area are JOM (2.59\% share), The International Journal of Life Cycle Assessment (2.59\% share), and Waste Management and Research (2.16\% share). Finally, reviewing tables in this study confirmed that the ELV management is considered by numerous journals.

\section{Conclusions}

This paper presents a comprehensive literature review of the ELV management research area. Totally, 232 studies published in the period 2000-2019 are collected, categorized, reviewed and analyzed. The review has shown that there is a significant increase in the number of studies after the year 2011. Most researchers focused their attention only on the managerial perspective. The vast majority of researchers used only deterministic parameters. Only a few researchers suggested a solution for both open- and closed-loop supply chains. The studies with mathematical models mainly considered location-allocation problems. These studies were mostly formulated as linear programs. Attention to multiobjective problem formulations is low. The studies almost exclusively considered cost or profit as its only objective function. Exact solution methods are mostly provided. However, the vast majority of reviewed studies were illustrated in either small- or medium-size cases. It should be outlined that when solving real-life large-scale problems, this solution approach is significantly limited. It is found that the Journal of Cleaner Production, Resources, Conservation and Recycling, and Waste Management represent primary publication outlets for the investigated research area.

According to the performed review, the following gaps and potential research directions for their improvements are noticed:

- Social acceptance and social awareness are important problems to deal with for effective ELV management. There are not enough studies that include social criteria.

- Researches of environmental consequences of introducing or extending the ELV logistics network are missing.

- Material waste reductions, recyclability of materials and innovative forming processes able to recycle materials have to be considered in more detail.

- The research on more profitable and ecologically efficient treatment options represents an interesting avenue for further research.

- Little has been done to document present industry practices in case studies or surveys.

- Uncertainty is the key factor influencing the ELV management. However, uncertainty analysis is mainly 
ignored in the available studies. Uncertainty analysis methods incorporated into future modeling frameworks could help to avoid erroneous strategic decisions.

- Resource scarcity and volatile quantities of ELVs introduce risk in management systems. The available models can hardly provide network designs appealing to riskaverse waste managers. In fact, they can generate less reliable and inferior solutions. Thus, risk measurement methods integration into future optimization frameworks is one of the possible improvements.

This review can provide a source of references, valuable insights, and opportunities for researchers interested in the ELV management and inspire their additional attention.

Acknowledgements The authors are grateful for the valuable comments of the Editor-in-Chief and the three anonymous reviewers, which help to improve the manuscript greatly.

Open Access This article is distributed under the terms of the Creative Commons Attribution 4.0 International License (http://creativeco mmons.org/licenses/by/4.0/), which permits unrestricted use, distribution, and reproduction in any medium, provided you give appropriate credit to the original author(s) and the source, provide a link to the Creative Commons license, and indicate if changes were made.

\section{References}

1. OECD Statistics (2019) Passenger car registrations (indicator). https://data.oecd.org/transport/passenger-car-registrations.htm. Accessed 14 May 19

2. Statista Portal (2019) Worldwide automobile production from 2000 to 2017 (in million vehicles). https://www.statista.com/stati stics/262747/worldwide-automobile-production-since-2000/. Accessed 09 May 19

3. Simic V (2013) End-of-life vehicle recycling-a review of the state-of-the-art. Technical Gazette 20(2):371-380

4. Simic V (2016) Interval-parameter chance-constraint programming model for end-of-life vehicles management under rigorous environmental regulations. Waste Manage 52:180-192

5. Raja Mamat TNA, Saman MZM, Sharif S, Simic V, Abd Wahab D (2018) Development of a performance evaluation tool for endof-life vehicle management system implementation using the analytic hierarchy process. Waste Manage Res 36(12):1210-1222

6. WRME (2014) Waste and recycling-Middle East (WRME), Special supplement: auto recycling, 2014/2015. http://waste -recyclingme.ae/WR\%20-Suppliment\%202014-15.pdf. Accessed 09 May 19

7. EU (2000) Directive 2000/53/EC of the European parliament and of the council of 18 September 2000 on end-of-life vehicles. Official Journal of the European Union L269, 34-42. https:// eur-lex.europa.eu/legal-content/EN/ALL/?uri=CELEX\%3A320 00L0053. Accessed 09 May 19

8. Ministry of the Environment (MOE) (2002) Law on recycling of end-of-life vehicles. https://www.meti.go.jp/policy/recycle/main/ english/law/end.html. Accessed 09 May 19

9. National Development and Reform Commission (NDRC) (2006) Technical policy for the recovery and utilization of automobile products. http://www.asianlii.org/cn/legis/cen/laws/ttpftrauoa p730/. Accessed 09 May 19
10. Ministry of the Environment (MOE) (2010) Act on resource circulation of electrical and electronic equipment and vehicles. http://extwprlegs1.fao.org/docs/pdf/kor169190.pdf. Accessed 09 May 19

11. Duriau VJ, Reger RK, Pfarrer MD (2007) A content analysis of the content analysis literature in organization studies: research themes, data sources, and methodological refinements. Org Res meThods 10(1):5-34

12. Nourreddine M (2007) Recycling of auto shredder residue. J Hazard Mater A139:481-490

13. Kumar V, Sutherland JW (2008) Sustainability of the automotive recycling infrastructure: review of current research and identification of future challenges. Int J Sustain Manuf 1(1-2):145-167

14. Bari MA, Kindzierski WB, Lashaki MJ, Hashisho Z (2011) Automotive wastes. Water Environ Res 83(10):1467-1487

15. Kindzierski WB, Bari MA, Hashisho Z, Reid B, Shariaty P (2013) Automotive wastes. Water Environ Res 85(10):1452-1473

16. Vermeulen I, Van Caneghem J, Block C, Baeyens J, Vandecasteele C (2011) Automotive shredder residue (ASR): reviewing its production from end-of-life vehicles (ELVs) and its recycling, energy or chemicals' valorisation. J Hazard Mater 190(1-3):8-27

17. Go TF, Wahab DA, Rahman MA, Ramli R, Azhari CH (2011) Disassemblability of end-of-life vehicle: a critical review of evaluation methods. J Clean Prod 19(13):1536-1546

18. Zorpas AA, Inglezakis VJ (2012) Automotive industry challenges in meeting EU 2015 environmental standard. Technol Soc 34(1):55-83

19. Mayyas A, Qattawi A, Omar M, Shan D (2012) Design for sustainability in automotive industry: a comprehensive review. Renew Sustain Energy Rev 16(4):1845-1862

20. Lashlem AA, Wahab DA, Abdullah S, Che Haron CH (2013) A review on end-of-life vehicle design process and management. J Appl Sci 13(5):654-662

21. Gan JW, He ZG (2014) Literature review and prospect on the end-of-life vehicles reverse logistics. Adv Mater Res 878:66-74

22. Li J, Yu K, Gao P (2014) Recycling and pollution control of the end of life vehicles in China. J Mater Cycles Waste Manage 16(1):31-38

23. Sakai SI, Yoshida H, Hiratsuka J, Vandecasteele C, Kohlmeyer R, Rotter VS et al (2014) An international comparative study of end-of-life vehicle (ELV) recycling systems. J Mater Cycles Waste Manage 16:1-20

24. Hiratsuka J, Sato N, Yoshida H (2014) Current status and future perspectives in end-of-life vehicle recycling in Japan. J Mater Cycles Waste Manage 16(1):21-30

25. Buekens A, Zhou X (2014) Recycling plastics from automotive shredder residues: a review. J Mater Cycles Waste Manage 16(3):398-414

26. Zhang H, Chen M (2014) Current recycling regulations and technologies for the typical plastic components of end-of-life passenger vehicles: a meaningful lesson for China. J Mater Cycles Waste Manage 16(2):187-200

27. Cossu R, Lai T (2015) Automotive shredder residue (ASR) management: an overview. Waste Manage 45:143-151

28. Cucchiella F, D’Adamo I, Rosa P, Terzi S (2016) Scrap automotive electronics: a mini-review of current management practices. Waste Manage Res 34(1):3-10

29. Rosa P, Terzi S (2016) Waste Electrical and Electronic Equipments versus End of Life Vehicles: a state of the art analysis and quantification of potential profits. In: Proceedings of the 23rd CIRP international conference on life cycle engineering, Berlin, Germany, pp. 502-507

30. Cin E, Kusakcı AO (2017) A literature survey on reverse logistics of end of life vehicles. Southeast Europe J Soft Comput 6:1

31. De Almeida ST, Borsato M (2019) Assessing the efficiency of End of Life technology in waste treatment-a bibliometric literature review. Resour Conserv Recycl 140:189-208 
32. Kirkpatrick N, Dowdell D, Glazebrook B (2000) A life cycle assessment of the implications of implementing the proposed end of life vehicles directive in the United Kingdom (No. 200001-1468). In: SAE Technical Paper

33. Bellmann K, Khare A (2000) Economic issues in recycling end-of-life vehicles. Technovation 20(12):677-690

34. Hartman H, Hernborg N, Malmsten J (2000) Increased Re-use of components from ELV's: a sign of customer and environmental care (No. 2000-01-1513). In: SAE Technical Paper

35. Díaz V, Fernández MG (2001) Treatment centre of end-of-life vehicles (No. 2001-01-3745). In: SAE Technical Paper

36. Mark FE, Niewerth C, Slik G (2001) Optimization of instrument panels to assist recycling quota-dismantling/mechanical recycling vs. ASR treatment/chemical recycling (No. 2001-013741). In: SAE Technical Paper

37. Johnson MR, Wang MH (2001) Sustainability and management of end-of-life vehicles (ELVs) within the European Union's Directive on ELVs (No. 2001-01-3735). In: SAE Technical Paper

38. Petrov RL (2001) The Concept of End-of-Life Car Rcycling System in Russia (No. 2001-01-0696). In: SAE Technical Paper

39. Johnson MR, Wang MH (2002) Evaluation policies and automotive recovery options according to the European Union directive on end-of-life vehicles (ELV). Proc Inst Mech Engineers Part D J Automobile Eng 216(9):723-739

40. Van Schaik A, Reuter MA, Boin UMJ, Dalmijn WL (2002) Dynamic modelling and optimisation of the resource cycle of passenger vehicles. Miner Eng 15(11):1001-1016

41. Boon JE, Isaacs JA, Gupta SM (2003) End-of-life infrastructure economics for "clean vehicles" in the United States. J Ind Ecol 7(1):25-45

42. Petrov RL (2003) The evolution of LADA cars recyclability (No. 2003-01-2822). In: SAE Technical Paper

43. Castro MB, Remmerswaal JA, Reuter MA (2003) Life cycle impact assessment of the average passenger vehicle in the Netherlands. Int J Life Cycle Assessment 8(5):297-304

44. Gesing A (2004) Assuring the continued recycling of light metals in end-of-life vehicles: a global perspective. JOM 56(8):18-27

45. Mark FE, Kamprath AE (2004) End-of-life vehicles recovery and recycling polyurethane seat cushion recycling options analysis (No. 2004-01-0249). In: SAE Technical Paper

46. Van Schaik A, Reuter MA (2004) The time-varying factors influencing the recycling rate of products. Resour Conserv Recycl 40(4):301-328

47. Van Schaik A, Reuter MA, Heiskanen K (2004) The influence of particle size reduction and liberation on the recycling rate of end-of-life vehicles. Miner Eng 17(2):331-347

48. Kim KH, Joung HT, Nam H, Seo YC, Hong JH, Yoo TW, Park $\mathrm{JH}$ et al (2004) Management status of end-of-life vehicles and characteristics of automobile shredder residues in Korea. Waste Manage 24(6):533-540

49. Schmidt WP, Dahlqvist E, Finkbeiner M, Krinke S, Lazzari S, Oschmann D et al (2004) Life cycle assessment of lightweight and end-of-life scenarios for generic compact class passenger vehicles. Int J Life Cycle Assess 9(6):405-416

50. Pelletiere D, Reinert KA (2004) Used automobile protection and trade: gravity and ordered probit analysis. Empirical Econ 29(4):737-751

51. Bandivadekar AP, Kumar V, Gunter KL, Sutherland JW (2004) A model for material flows and economic exchanges within the US automotive life cycle chain. J Manuf Syst 23(1):22-29

52. Sawyer-Beaulieu SS, Tam EK (2005) Applying life cycle assessment (LCA) to North American end-of-life vehicle (ELV) management processes (No. 2005-01-0846). In: SAE Technical Paper

53. Seo YC, Joung HT, Hong JH, Yoo TW, Kim KH, Lim BS, et al. (2005) Management of End-of-Life Vehicles and
Characterization of Automobile Shredder Residue in Korea (No. 2005-01-0845). In: SAE Technical Paper

54. Choi JK, Stuart JA, Ramani K (2005) Modeling of automotive recycling planning in the United States. Int J Automot Technol 6(4):413-419

55. Castro MB, Remmerswaal JAM, Brezet JC, Van Schaik A, Reuter MA (2005) A simulation model of the comminutionliberation of recycling streams: relationships between product design and the liberation of materials during recycling. Int $\mathbf{J}$ Miner Process 75(3-4):255-281

56. Forslind KH (2005) Implementing extended producer responsibility: the case of Sweden's car scrapping scheme. J Clean Prod 13(6):619-629

57. Chen M (2006) Sustainable recycling of automotive products in China: technology and regulation. JOM 58(8):23-26

58. Ferrao P, Nazareth P, Amaral J (2006) Strategies for meeting EU end-of-life vehicle reuse/recovery targets. J Ind Ecol 10(4):77-93

59. Krinke S, Bossdorf-Zimmer B, \& Goldmann D (2006) The Volkswagen-SiCon process: eco-efficient solution for future end-of-life vehicle treatment. In: Proceedings of the 13th CIRP International Conference on Life Cycle Engineering, Leuven, Belguim, pp 359-363

60. Reuter MA, Van Schaik A, Ignatenko O, De Haan GJ (2006) Fundamental limits for the recycling of end-of-life vehicles. Miner Eng 19(5):433-449

61. Forton OT, Harder MK, Moles NR (2006) Value from shredder waste: ongoing limitations in the UK. Resour Conserv Recycl 46(1):104-113

62. Finkbeiner M, Hoffmann R (2006) Application of life cycle assessment for the environmental certificate of the MercedesBenz S-Class (7 pp). Int J Life Cycle Assess 11(4):240-246

63. Mazzanti M, Zoboli R (2006) Economic instruments and induced innovation: the European policies on end-of-life vehicles. Ecol Econ 58(2):318-337

64. Amaral J, Ferrao P, Rosas C (2006) Is recycling technology innovation a major driver for technology shift in the automobile industry under an EU context? Int J Technol Policy Manage 6(4):385-398

65. Ferrao P, Amaral J (2006) Assessing the economics of auto recycling activities in relation to European Union Directive on end of life vehicles. Technol Forecast Soc Chang 73(3):277-289

66. Pelletiere D, Reinert KA (2006) World trade in used automobiles: a gravity analysis of Japanese and US exports. Asian Econ J 20(2):161-172

67. Coates G, Rahimifard S (2007) Assessing the economics of prefragmentation material recovery within the UK. Resour Conserv Recycl 52(2):286-302

68. Jeong KM, Hong SJ, Lee JY, Hur T (2007) Life cycle assessment on end-of-life vehicle treatment system in Korea. J Ind Eng Chem 13(4):624-630

69. Joung HT, Cho SJ, Seo YC, Kim WH (2007) Status of recycling end-of-life vehicles and efforts to reduce automobile shredder residues in Korea. J Mater Cycles Waste Manage 9(2):159-166

70. Mergias I, Moustakas K, Papadopoulos A, Loizidou M (2007) Multi-criteria decision aid approach for the selection of the best compromise management scheme for ELVs: the case of Cyprus. J Hazard Mater 147(3):706-717

71. Dalmijn WL, De Jong TPR (2007) The development of vehicle recycling in Europe: sorting, shredding, and separation. JOM 59(11):52-56

72. Giannouli M, de Haan P, Keller M, Samaras Z (2007) Waste from road transport: development of a model to predict waste from end-of-life and operation phases of road vehicles in Europe. J Clean Prod 15(11-12):1169-1182 
73. Sakai SI, Noma Y, Kida A (2007) End-of-life vehicle recycling and automobile shredder residue management in Japan. J Mater Cycles Waste Manage 9(2):151-158

74. Williams JAS, Wongweragiat S, Qu X, McGlinch JB, Bonawitan W, Choi JK, Schiff J (2007) An automotive bulk recycling planning model. Eur J Oper Res 177(2):969-981

75. Alonso JC, Dose J, Fleischer G, Geraghty K, Greif A, Rodrigo $\mathrm{J}$ et al (2007) Electrical and electronic components in the automotive sector: economic and environmental assessment. Int $\mathbf{J}$ Life Cycle Assess 12(5):328

76. Frad A, Revnic I (2007) Prodtect automotive-meeting the requirements of ELV. In: Proceedings of the international conference on engineering design, Paris, France, pp 28-31

77. Ribeiro C, Ferreira JV, Partidário P (2007) Life cycle assessment of a multi-material car component. Int J Life Cycle Assess 12(5):336

78. Fuse M, Nakajima K, Yagita H (2007) Outflow of resources from Japan focusing on end-of-life vehicles. Mater Trans 48(9):2436-2444

79. Ignatenko O, Van Schaik A, Reuter MA (2008) Recycling system flexibility: the fundamental solution to achieve high energy and material recovery quotas. J Clean Prod 16(4):432-449

80. Qi Z, Hongcheng W (2008) Research on construction mode of recycling network of reverse logistics of automobile enterprises. In: Proceedings of international conference on information management, innovation management and industrial engineering, vol. 3, 19-21 December, Taipei, Taiwan, pp 36-40. IEEE Computer Society, Los Alamitos, CA, USA

81. Sawyer-Beaulieu SS, Tam EK (2008) Constructing a gate-togate life cycle inventory (LCI) of end-of-life vehicle (ELV) dismantling and shredding processes (No. 2008-01-1283). In: SAE Technical Paper

82. Smith VM, Keoleian GA (2008) The value of remanufactured engines: life-cycle environmental and economic perspectives. J Ind Ecol 8(1-2):193-221

83. Fuse M, Kashima S (2008) Evaluation method of automobile recycling systems for Asia considering international material cycles: application to Japan and Thailand. J Mater Cycles Waste Manage 10(2):153-164

84. Qu X, Williams JAS (2008) An analytical model for reverse automotive production planning and pricing. Eur J Oper Res 190(3):756-767

85. Chondros TG (2009) End of life vehicles recycling: a state-ofthe-art review. Int J Terraspace Sci Eng 2:19-38

86. Puri P, Compston P, Pantano V (2009) Life cycle assessment of Australian automotive door skins. Int J Life Cycle Assess 14(5):420-428

87. Amelia L, Wahab DA, Haron CC, Muhamad N, Azhari CH (2009) Initiating automotive component reuse in Malaysia. J Clean Prod 17(17):1572-1579

88. Chen M, Zhang F (2009) End-of-life vehicle recovery in China: consideration and innovation following the EU ELV directive. JOM 61(3):45-52

89. Kumar V, Sutherland JW (2009) Development and assessment of strategies to ensure economic sustainability of the US automotive recovery infrastructure. Resour Conserv Recycl 53(8):470-477

90. Fuse M, Kosaka H, Kashima S (2009) Estimation of world trade for used automobiles. J Mater Cycles Waste Manage 11(4):348

91. Fuse M, Nakajima K, Yagita H (2009) Global flow of metal resources in the used automobile trade. Mater Trans 50(4):703-710

92. Santini A, Herrmann C, Passarini F, Vassura I, Luger T, Morselli L (2010) Assessment of Ecodesign potential in reaching new recycling targets. Resour Conserv Recycl 54(12):1128-1134
93. Chen KC, Huang SH, Lian IW (2010) The development and prospects of the end-of-life vehicle recycling system in Taiwan. Waste Manage 30(8-9):1661-1669

94. Go TF, Wahab DA, Rahman MA, Ramli R (2010) A design framework for end-of-life vehicles recovery: optimization of disassembly sequence using genetic algorithms. Am J Environ Sci 6(4):350

95. Mathieux F, Brissaud D (2010) End-of-life product-specific material flow analysis. Application to aluminum coming from end-of-life commercial vehicles in Europe. Resourc Conserv Recycl 55(2):92-105

96. Agbo COA (2011) Recycle materials potential of imported used vehicles in Nigeria. Nigerian J Technol 30(3):118-128

97. Duranceau CM, Sawyer-Beaulieu S (2011) Vehicle recycling, reuse, and recovery: Material disposition from current end-of-life vehicles (No. 2011-01-1151). In: SAE Technical Paper

98. Hedayati M, Subic A (2011) A framework for extended end-oflife vehicle (ELV) recovery rate based on a sustainable treatment option. Int J Sustain Design 1(4):381-401

99. Kibira D, Jain S (2011) Impact of hybrid and electric vehicles on automobile recycling infrastructure. In: proceedings of winter simulation conference, Phoenix, Arizona, USA, pp 1072-1083

100. Santini A, Morselli L, Passarini F, Vassura I, Di Carlo S, Bonino F (2011) End-of-Life vehicles management: Italian material and energy recovery efficiency. Waste Manage 31(3):489-494

101. Xi L, Yu W, Li S (2011) Assessment of the reused components of an end-of-life vehicle based on strengthening characteristic. Adv Sci Lett 4(4-5):1643-1647

102. Zoraga M, Cumbul Altay M, Sivri N, Onat B, \& Kahruman C (2009) Aluminum recovery and environmental effects in scrap cars. In: Proceedings of 4th aluminum symposium, Istanbul, Turkey, pp 106-113

103. Che J, Yu JS, Kevin RS (2011) End-of-life vehicle recycling and international cooperation between Japan, China and Korea: present and future scenario analysis. J Env Sci 23:162-166

104. Nazmi MASM, Wahab DA, Abdullah S, Tihth RM (2011) Development of artificial neural network for optimisation of reusability in automotive components. J Appl Sci 11(6):996-1003

105. Filho JJ (2012) Treatment of end of life vehicles in Brazil: challenges and opportunities (No. 2012-36-0217). In: SAE Technical Paper

106. Fiore S, Ruffino B, Zanetti MC (2012) Automobile shredder residues in Italy: characterization and valorization opportunities. Waste Manage 32(8):1548-1559

107. Millet D, Yvars PA, Tonnelier P (2012) A method for identifying the worst recycling case: application on a range of vehicles in the automotive sector. Resour Conserv Recycl 68:1-13

108. Nakamura S, Kondo Y, Matsubae K, Nakajima K, Tasaki T, Nagasaka T (2012) Quality-and dilution losses in the recycling of ferrous materials from end-of-life passenger cars: input-output analysis under explicit consideration of scrap quality. Environ Sci Technol 46(17):9266-9273

109. Santini A, Passarini F, Vassura I, Serrano D, Dufour J, Morselli L (2012) Auto shredder residue recycling: mechanical separation and pyrolysis. Waste Manage 32(5):852-858

110. Cheng YW, Cheng JH, Wu CL, Lin CH (2012) Operational characteristics and performance evaluation of the ELV recycling industry in Taiwan. Resour Conserv Recycl 65:29-35

111. Hatayama H, Daigo I, Matsuno Y, Adachi Y (2012) Evolution of aluminum recycling initiated by the introduction of next-generation vehicles and scrap sorting technology. Resour Conserv Recycl 66:8-14

112. Wang J, Chen M (2012) Management status of end-of-life vehicles and development strategies of used automotive electronic control components recycling industry in China. Waste Manage Res 30(11):1198-1207 
113. Simic V, Dimitrijevic B (2012) Modelling production processes in a vehicle recycling plant. Waste Manage Res 30(9):940-948

114. Simic V, Dimitrijevic B (2012) Production planning for vehicle recycling factories in the EU legislative and global business environments. Resour Conserv Recycl 60:78-88

115. Arena M, Azzone G, Conte A (2013) A streamlined LCA framework to support early decision making in vehicle development. $\mathrm{J}$ Clean Prod 41:105-113

116. Simic V, Dimitrijevic B (2013) Modelling of automobile shredder residue recycling in the Japanese legislative context. Expert Syst Appl 40(18):7159-7167

117. Simic V, Dimitrijevic B (2013) Risk explicit interval linear programming model for long-term planning of vehicle recycling in the EU legislative context under uncertainty. Resour Conserv Recycl 73:197-210

118. Berzi L, Delogu M, Giorgetti A, Pierini M (2013) On-field investigation and process modelling of end-of-life vehicles treatment in the context of Italian craft-type authorized treatment facilities. Waste Manage 33(4):892-906

119. Tasala Gradin K, Luttropp C, Björklund A (2013) Investigating improved vehicle dismantling and fragmentation technology. J Clean Prod 54:23-29

120. Saavedra YM, Barquet AP, Rozenfeld H, Forcellini FA, Ometto AR (2013) Remanufacturing in Brazil: case studies on the automotive sector. J Clean Prod 53:267-276

121. Schmid A, Naquin P, Gourdon R (2013) Incidence of the level of deconstruction on material reuse, recycling and recovery from end-of life vehicles: an industrial-scale experimental study. Resour Conserv Recycl 72:118-126

122. Hu S, Kurasaka H (2013) Projection of end-of-life vehicle (ELV) population at provincial level of China and analysis on the gap between the future requirements and the current situation of ELV treatment in China. J Mater Cycles Waste Manage 15(2):154-170

123. Miller L, Soulliere K, Sawyer-Beaulieu S, Tseng S, Tam E (2014) Challenges and alternatives to plastics recycling in the automotive sector. Materials 7(8):5883-5902

124. Ruffino B, Fiore S, Zanetti MC (2014) Strategies for the enhancement of automobile shredder residues (ASRs) recycling: results and cost assessment. Waste Manage 34(1):148-155

125. Sawyer-Beaulieu SS, Stagner JA, Tam EK (2014) Sustainability issues affecting the successful management and recycling of endof-life vehicles in Canada and the United States. In: Environmental Issues in Automotive Industry (pp 223-245). Springer, Berlin, Heidelberg

126. Tian J, Chen M (2014) Sustainable design for automotive products: dismantling and recycling of end-of-life vehicles. Waste Manage 34(2):458-467

127. Ahmed S, Shamsuddin Ahmed M, Shumon RH, Quader MA (2014) End-of-life vehicles (ELVs) management and future transformation in Malaysia. J Appl Sci Agric 9:227-237

128. Lu Y, Broughton J, Winfield P (2014) A review of innovations in disbonding techniques for repair and recycling of automotive vehicles. Int J Adhes Adhes 50:119-127

129. Yano J, Hirai Y, Okamoto K, Sakai SI (2014) Dynamic flow analysis of current and future end-of-life vehicles generation and lead content in automobile shredder residue. J Mater Cycles Waste Manage 16(1):52-61

130. El Halabi E, Third M, \& Doolan M (2015) Machine-based dismantling of end of life vehicles: a life cycle perspective. In: Proceedings of the 22nd CIRP conference on life cycle engineering, Sydney, Australia, pp 651-655

131. Chen Z, Chen D, Wang T, Hu S (2015) Policies on end-of-life passenger cars in China: dynamic modeling and cost-benefit analysis. J Clean Prod 108:1140-1148

132. Despeisse M, Kishita Y, Nakano M, Barwood M (2015) Towards a circular economy for end-of-life vehicles: a comparative study
UK-Japan. In: Proceedings of the 22nd CIRP conference on life cycle engineering, Sydney, Australia, pp 668-673

133. Ohno H, Matsubae K, Nakajima K, Kondo Y, Nakamura S, Nagasaka T (2015) Toward the efficient recycling of alloying elements from end of life vehicle steel scrap. Resour Conserv Recycl 100:11-20

134. Sawyer-Beaulieu S, Tam EK (2015) Maximizing automotive parts reuse, remanufacturing, and recycling through effective end-of-life vehicle management: a different perspective on what needs to be done. SAE Int J Mater Manuf 8(1):118-127

135. Yi HC, Park JW (2015) Design and implementation of an endof-life vehicle recycling center based on IoT (Internet of Things) in Korea. In: Proceedings of the 22nd CIRP conference on life cycle engineering, Sydney, Australia, pp 728-733

136. Simic V, Dimitrijevic B (2015) Interval linear programming model for long-term planning of vehicle recycling in the Republic of Serbia under uncertainty. Waste Manage Res 33(2):114-129

137. Oguchi M, Fuse M (2015) Regional and longitudinal estimation of product lifespan distribution: a case study for automobiles and a simplified estimation method. Environ Sci Technol 49(3):1738-1743

138. Belboom S, Lewis G, Bareel PF, Léonard A (2016) Life cycle assessment of hybrid vehicles recycling: comparison of three business lines of dismantling. Waste Manage 50:184-193

139. Desnica E, Vulić M, Nikolić M (2016) AHP method in the function of adequate equipment choice for ELV detoxification in Serbia and EU. Appl Eng Lett 1(4):115-121

140. Inghels D, Dullaert W, Raa B, Walther G (2016) Influence of composition, amount and life span of passenger cars on endof-life vehicles waste in Belgium: a system dynamics approach. Transp Res Part A Policy Practice 91:80-104

141. Junior EO, Luiz A, Serigiolle L, Marcial M (2016) End-of-life vehicle recycling: Processes, legislations and benefits (No. 201636-0426). In: SAE Technical Paper

142. Pan Y, Li H (2016) Sustainability evaluation of end-of-life vehicle recycling based on emergy analysis: a case study of an end-of-life vehicle recycling enterprise in China. J Clean Prod 131:219-227

143. Ahmed S, Ahmed S, Shumon MRH, Falatoonitoosi E, Quader MA (2016) A comparative decision-making model for sustainable end-of-life vehicle management alternative selection using AHP and extent analysis method on fuzzy AHP. Int J Sustain Dev World Ecol 23(1):83-97

144. Ahmed S, Ahmed S, Shumon MRH, Quader MA, Cho HM, Mahmud MI (2016) Prioritizing strategies for sustainable end-of-life vehicle management using combinatorial multi-criteria decision making method. Int J Fuzzy Syst 18(3):448-462

145. Pourjavad E, Mayorga RV (2016) A combined fuzzy approach to determine sustainable ELV strategy. Int J Transp Syst 1:78-83

146. Pourjavad E, Mayorga RV (2016) A hybrid approach integrating AHP and TOPSIS for sustainable end-of-life vehicle strategy evaluation under fuzzy environment. WSEAS Trans Circ Syst $15: 216-223$

147. Raja Mamat TNA, Saman MZM, Sharif S, Simic V (2016) Key success factors in establishing end-of-life vehicle management system: a primer for Malaysia. J Clean Prod 135:1289-1297

148. Li W, Bai H, Yin J, Xu H (2016) Life cycle assessment of endof-life vehicle recycling processes in China-take Corolla taxis for example. J Clean Prod 117:176-187

149. Tian J, Chen M (2016) Assessing the economics of processing end-of-life vehicles through manual dismantling. Waste Manage 56:384-395

150. Xia X, Li J, Tian H, Zhou Z, Li H, Tian G, Chu J (2016) The construction and cost-benefit analysis of end-of-life vehicle disassembly plant: a typical case in China. Clean Technol Environ Policy 18(8):2663-2675 
151. Zhou F, Lin Y, Wang X, Zhou L, He Y (2016) ELV recycling service provider selection using the hybrid MCDM method: a case application in China. Sustainability 8(5):482

152. Diener DL, Tillman AM (2016) Scrapping steel components for recycling - isn't that good enough? Seeking improvements in automotive component end-of-life. Resour Conserv Recycl 110:48-60

153. Xu G, Yano J, Sakai SI (2016) Scenario analysis for recovery of rare earth elements from end-of-life vehicles. J Mater Cycles Waste Manage 18(3):469-482

154. Yano J, Muroi T, Sakai SI (2016) Rare earth element recovery potentials from end-of-life hybrid electric vehicle components in 2010-2030. J Mater Cycles Waste Manage 18(4):655-664

155. Andersson M, Söderman ML, Sandén BA (2017) Are scarce metals in cars functionally recycled? Waste Manage 60:407-416

156. Ene S, Öztürk N (2017) Grey modelling based forecasting system for return flow of end-of-life vehicles. Technol Forecast Soc Chang 115:155-166

157. Gan J, Luo L (2017) Using DEMATEL and intuitionistic fuzzy sets to identify critical factors influencing the recycling rate of end-of-life vehicles in China. Sustainability 9(10):1873

158. Karaeen, M, Hanieh AA, AbdElall S, Sughayyer M, Hasan A (2017) Concept model for the second life cycle of vehicles in Palestine. In: Proceedings of the 14th global conference on sustainable manufacturing, GCSM, Stellenbosch, South Africa, pp 707-714

159. Soo VK, Peeters J, Compston P, Doolan, M, \& Duflou, JR (2017a) Comparative study of end-of-life vehicle recycling in Australia and Belgium. In: Proceedings of the 24th CIRP conference on life cycle engineering, Kamakura, Japan, pp 651-655

160. Soo VK, Compston P, Doolan M (2017) The influence of joint technologies on ELV recyclability. Waste Manage 68:421-433

161. Nakano K, Shibahara N (2017) Comparative assessment on greenhouse gas emissions of end-of-life vehicles recycling methods. J Mater Cycles Waste Manage 19(1):505-515

162. Endo K, Fuse M (2017) Uncertainty analysis of global reuse monitoring. In: Proceedings of the 24th CIRP Conference on Life Cycle Engineering, Kamakura, Japan, pp 172-176

163. Khodier A, Williams K, Dallison N (2018) Challenges around automotive shredder residue production and disposal. Waste Manage 73:566-573

164. Zhang C, Chen M (2018) Prioritising alternatives for sustainable end-of-life vehicle disassembly in China using AHP methodology. Technol Anal Strategic Manag 30(5):556-568

165. Hao H, Zhang Q, Wang Z, Zhang J (2018) Forecasting the number of end-of-life vehicles using a hybrid model based on grey model and artificial neural network. J Clean Prod 202:684-696

166. Mohan TK, Amit RK (2018) Dismantlers' dilemma in end-of-life vehicle recycling markets: a system dynamics model. Ann Oper Res 2018:1-29

167. Rosa P, Terzi S (2018) Improving end of life vehicle's management practices: an economic assessment through system dynamics. J Clean Prod 184:520-536

168. Zhang C, Chen M (2018) Designing and verifying a disassembly line approach to cope with the upsurge of end-of-life vehicles in China. Waste Manage 76:697-707

169. Wong YC, Al-Obaidi KM, Mahyuddin N (2018) Recycling of end-of-life vehicles (ELVs) for building products: concept of processing framework from automotive to construction industries in Malaysia. J Clean Prod 190:285-302

170. Ortego A, Valero A, Valero A, Iglesias M (2018) Downcycling in automobile recycling process: a thermodynamic assessment. Resour Conserv Recycl 136:24-32

171. Lin HT, Nakajima K, Yamasue E, Ishihara K (2018) Recycling of end-of-life vehicles in small Islands: the Case of Kinmen, Taiwan. Sustainability 10(12):4377
172. Xu G, Yano J, Sakai SI (2018) Recycling potentials of precious metals from end-of-life vehicle parts by selective dismantling. Environ Sci Technol 53(2):733-742

173. Miskolczi N, Juzsakova T, Sója J (2019) Preparation and application of metal loaded ZSM-5 and y-zeolite catalysts for thermocatalytic pyrolysis of real end of life vehicle plastics waste. $\mathrm{J}$ Energy Inst 92(1):118-127

174. Sato FEK, Furubayashi T, Nakata T (2019) Application of energy and $\mathrm{CO} 2$ reduction assessments for end-of-life vehicles recycling in Japan. Appl Energy 237:779-794

175. Arora N, Bakshi SK, Bhattacharjya S (2019) Framework for sustainable management of end-of-life vehicles management in India. J Mater Cycles Waste Manage 21(1):79-97

176. Mohamad-Ali N, Raja Ghazilla RA, Abdul-Rashid SH, AhmadYazid A (2019) Aftermarket survey on end-of-life vehicle recovery in Malaysia: key findings. J Clean Prod 211:468-480

177. Qiao Q, Zhao F, Liu Z, Hao H (2019) Electric vehicle recycling in China: economic and environmental benefits. Resour Conserv Recycl 140:45-53

178. Wang Z, Hao H, Gao F, Zhang Q, Zhang J, Zhou Y (2019) Multiattribute decision making on reverse logistics based on DEATOPSIS: a study of the Shanghai end-of-life vehicles industry. J Clean Prod 214:730-737

179. Yang Y, Hu J, Liu Y, Chen X (2019) Alternative selection of endof-life vehicle management in China: a group decision-making approach based on picture hesitant fuzzy measurements. J Clean Prod 206:631-645

180. Yano J, Xu G, Liu H, Toyoguchi T, Iwasawa H, Sakai SI (2019) Resource and toxic characterization in end-of-life vehicles through dismantling survey. J Mater Cycles Waste Manag 2019:1-17

181. Hoffmann U, Wilson B (2000) Requirements for, and benefits of, environmentally sound and economically viable management of battery recycling in the Philippines in the wake of Basel Convention trade restrictions. J Power Sources 88(1):115-123

182. Haefliger P, Mathieu-Nolf M, Lociciro S, Ndiaye C, Coly M, Diouf A, Junior APF et al (2009) Mass lead intoxication from informal used lead-acid battery recycling in Dakar. Senegal. Environmental Health Perspectives 117(10):1535-1540

183. Gottesfeld P, Were FH, Adogame L, Gharbi S, San D, Nota MM, Kuepouo G (2018) Soil contamination from lead battery manufacturing and recycling in seven African countries. Environ Res 161:609-614

184. Ericson B, Duong TT, Keith J, Nguyen TC, Havens D, Daniell W, Wilson B et al (2018) Improving human health outcomes with a low-cost intervention to reduce exposures from lead acid battery recycling: dong Mai, Vietnam. Env Res 161:181-187

185. Noguchi T, Itai T, Tue NM, Agusa T, Ha NN, Horai S, Tanabe $S$ et al (2014) Exposure assessment of lead to workers and children in the battery recycling craft village, Dong Mai, Vietnam. J Mater Cycles Waste Manag 16(1):46-51

186. Daniell WE, Van Tung L, Wallace RM, Havens DJ, Karr CJ, Bich Diep N, Duy Bao N (2015) Childhood lead exposure from battery recycling in Vietnam. BioMed Res Int 2015:1-10. https ://doi.org/10.1155/2015/193715

187. Eguchi A, Nomiyama K, Sakurai K, Trang PTK, Viet PH, Takahashi S, Mori C et al (2018) Alterations in urinary metabolomic profiles due to lead exposure from a lead-acid battery recycling site. Env Poll 242(A):98-105

188. Fujimori T, Eguchi A, Agusa T, Tue NM, Suzuki G, Takahashi S, Takigami $\mathrm{H}$ et al (2016) Lead contamination in surface soil on roads from used lead-acid battery recycling in Dong Mai, Northern Vietnam. J Mater Cycles Waste Manage 18(4):599-607

189. Ericson B, Landrigan P, Taylor MP, Frostad J, Caravanos J, Keith J, Fuller R (2016) The global burden of lead toxicity 
attributable to informal used lead-acid battery sites. Ann Glob Health 82(5):686-699

190. Ahn H, Keilen J, Souren R (2005) Recovery network design for end-of-life vehicles. In: Research methodologies in supply chain management (pp 555-570). Physica-Verlag HD

191. Schultmann F, Zumkeller M, Rentz O (2006) Modeling reverse logistic tasks within closed-loop supply chains: an example from the automotive industry. Eur J Oper Res 171(3):1033-1050

192. Mansour S, Zarei M (2008) A multi-period reverse logistics optimisation model for end-of-life vehicles recovery based on EU Directive. Int J Comput Integr Manuf 21(7):764-777

193. Cruz-Rivera R, Ertel J (2009) Reverse logistics network design for the collection of end-of-life vehicles in Mexico. Eur J Oper Res 196(3):930-939

194. Merkisz-Guranowska A (2010) Issues related to the optimization of location of vehicle recycling network entities. Arch Transp 22:303-318

195. Merkisz-Guranowska A (2011) End-of-life vehicles recycling network design. J KONES 18:261-268

196. Zarei M, Mansour S, Husseinzadeh Kashan A, Karimi B (2010) Designing a reverse logistics network for end-of-life vehicles recovery. Math Probl Eng

197. Harraz NA, Galal NM (2011) Design of sustainable endof-life vehicle recovery network in Egypt. Ain Shams Eng J 2(3-4):211-219

198. Mahmoudzadeh M, Mansour S, Karimi B (2011) A decentralized reverse logistics network for end of life vehicles from third party provider perspective. In: Proceedings of the 2 nd international conference on environmental science and technology, Singapore, pp 2338-2342

199. Vidovic M, Dimitrijevic B, Ratkovic B, Simic V (2011) A novel covering approach to positioning ELV collection points. Resour Conserv Recycl 57:1-9

200. Merkisz-Guranowska A (2012) Bicriteria models of vehicles recycling network facility location. Arch Transp 24:187-202

201. Merkisz-Guranowska A (2013) Multicriteria optimization model for end-of-life vehicles' recycling network. Int J Sustain Dev Plan 8(1):88-99

202. Farel R, Yannou B, Bertoluci G (2013) Finding best practices for automotive glazing recycling: a network optimization model. J Clean Prod 52:446-461

203. Gołębiewski B, Trajer J, Jaros M, Winiczenko R (2013) Modelling of the location of vehicle recycling facilities: a case study in Poland. Resour Conserv Recycl 80:10-20

204. Mahmoudzadeh M, Mansour S, Karimi B (2013) To develop a third-party reverse logistics network for end-of-life vehicles in Iran. Resour Conserv Recycl 78:1-14

205. Ene S, Öztürk N (2015) Network modeling for reverse flows of end-of-life vehicles. Waste Manage 38:284-296

206. Simic V (2015) A two-stage interval-stochastic programming model for planning end-of-life vehicles allocation under uncertainty. Resour Conserv Recycl 98:19-29

207. Simic V (2015) Fuzzy risk explicit interval linear programming model for end-of-life vehicle recycling planning in the EU. Waste Manage 35:265-282

208. Subulan K, Taşan AS, Baykasoğlu A (2015) A fuzzy goal programming model to strategic planning problem of a lead/acid battery closed-loop supply chain. J Manuf Syst 37:243-264

209. Alsaadi NA, Franchetti MJ (2016) An integrated approach to vehicle recycling facilities. Int J Env Sci Dev 7(11):856

210. Demirel E, Demirel N, Gökçen H (2016) A mixed integer linear programming model to optimize reverse logistics activities of end-of-life vehicles in Turkey. J Clean Prod 112:2101-2113

211. Simic V (2016) A multi-stage interval-stochastic programming model for planning end-of-life vehicles allocation. J Clean Prod 115:366-381
212. Simic V (2016) End-of-life vehicles allocation management under multiple uncertainties: an interval-parameter two-stage stochastic full-infinite programming approach. Resour Conserv Recycl 114:1-17

213. Phuc PNK, Vincent FY, Tsao YC (2017) Optimizing fuzzy reverse supply chain for end-of-life vehicles. Comput Ind Eng 113:757-765

214. Özceylan E, Demirel N, Çetinkaya C, Demirel E (2017) A closed-loop supply chain network design for automotive industry in Turkey. Comput Ind Eng 113:727-745

215. Deng H, Wang W, Zhao Y (2018) Optimization design of endof-life vehicle recycling system based on ExtendSim. Univ Politehnica Bucharest Sci Bull Ser C Electr Eng Comput Sci 80(3):95-108

216. Lin Y, Jia H, Yang Y, Tian G, Tao F, Ling L (2018) An improved artificial bee colony for facility location allocation problem of end-of-life vehicles recovery network. J Clean Prod 205:134-144

217. Shankar R, Bhattacharyya S, Choudhary A (2018) A decision model for a strategic closed-loop supply chain to reclaim Endof-Life Vehicles. Int J Prod Econ 195:273-286

218. Sun Y, Wang YT, Chen C, Yu B (2018) Optimization of a regional distribution center location for parts of end-of-life vehicles. Simulation 94(7):577-591

219. Ma H, Li X (2018) Closed-loop supply chain network design for hazardous products with uncertain demands and returns. Appl Soft Comput 68:889-899

220. Kuşakcı AO, Ayvaz B, Cin E, Aydın N (2019) Optimization of reverse logistics network of end of life vehicles under fuzzy supply: a case study for istanbul metropolitan area. J Clean Prod 215:1036-1051

221. Xiao Z, Sun J, Shu W, Wang T (2019) Location-allocation problem of reverse logistics for end-of-life vehicles based on the measurement of carbon emissions. Comput Ind Eng 127:169-181

222. Levizzari A, Bonino F, Corrias S (2002) Directive on end-of-life vehicles and its impact on the automotive Italian market: problems and opportunities. In: Proceedings of the international automobile recycling congress, Geneva, Switzerland, pp 239-242

223. Kanari N, Pineau JL, Shallari S (2003) End-of-life vehicle recycling in the European Union. JOM 55(8):15-19

224. Sakkas N, Manios T (2003) End of life vehicle management in areas of low technology sophistication. A case study in Greece. Business Strategy Env 12(5):313-325

225. Smith M, Jacobson J, Webb B (2004) Abandoned vehicles in England: impact of the end of life directive and new initiatives, on likely future trends. Resour Conserv Recycl 41(3):177-189

226. Chen M (2005) End-of-life vehicle recycling in China: now and the future. JOM 57(10):20-26

227. Marsh G (2005) Recycling collaborative combats legislation threat. Reinf Plast 49(8):24-28

228. Nakajima N, Vanderburg WH (2005) A failing grade for the German end-of-life vehicles take-back system. Bull Sci Technol Soc 25(2):170-186

229. Edwards C, Coates G, Leaney PG, Rahimifard S (2006) Implications of the End-of-Life Vehicles Directive on the vehicle recovery sector. Proc Inst Mech Engineers Part B J Eng Manuf 220(7):1211-1216

230. Saman MZM, Blount GN (2006) End of life vehicles recovery: process description, its impact and direction of research. JMekanikal 21(1):40-52

231. Gerrard J, Kandlikar M (2007) Is European end-of-life vehicle legislation living up to expectations? Assessing the impact of the ELV Directive on 'green' innovation and vehicle recovery. J Clean Prod 15(1): 17-27

232. Smink CK (2007) Vehicle recycling regulations: lessons from Denmark. J Clean Prod 15(11-12):1135-1146 
233. Manomaivibool P (2008) Network management and environmental effectiveness: the management of end-of-life vehicles in the United Kingdom and in Sweden. J Clean Prod 16(18):2006-2017

234. Smith M, Crotty J (2008) Environmental regulation and innovation driving ecological design in the UK automotive industry. Business Strategy Env 17(6):341-349

235. Konz RJ (2009) The end-of-life vehicle (ELV) directive: the road to responsible disposal. Minnesota J Int Law 18(2):431

236. Altay MC, Sivri N, Onat B, Şahin Ü, Zorağa M, Altay HF (2011) Recycle of metals for end-of-life vehicles (ELVs) and relation to Kyoto protocol. Renew Sustain Energy Rev 15(5):2447-2451

237. Zhao Q, Chen M (2011) A comparison of ELV recycling system in China and Japan and China's strategies. Resour Conserv Recycl 57:15-21
238. Wang L, Chen M (2013) Policies and perspective on end-of-life vehicles in China. J Clean Prod 44:168-176

239. Blume T, Walther M (2013) The end-of-life vehicle ordinance in the German automotive industry-corporate sense making illustrated. J Clean Prod 56:29-38

240. Farel R, Yannou B, Ghaffari A, Leroy Y (2013) A cost and benefit analysis of future end-of-life vehicle glazing recycling in France: a systematic approach. Resour Conserv Recycl 74:54-65

Publisher's Note Springer Nature remains neutral with regard to jurisdictional claims in published maps and institutional affiliations. 